\title{
TRANSFORMATION OF PERCEPTION OF THE GECEKONDU PHENOMENON
}

\author{
Mehmet Rifat AKBULUT, Seher BAŞLIK
}

Received: 19.07.2005; Final Text: 26.06.2010

Keywords: gecekondu; urban history; urbanization; urban transformation; Turkey.
The aim of this paper is not to redefine the gecekondu phenomenon, nor to describe its historical development, but to discuss and explore the transformations it is socially perceived with through time. Academic approaches are generally reviewed in a more pronounced manner. Within the frame of this paper gecekondu phenomenon is conceived according to different time periods well-known in gecekondu studies; i.e. from the 1940 s to 1970 as the 'period of innocence and marginalisation', the 1970s as period of 'politization' and 'first benefits of speculation', and from 1980 onwards as the period of the "varoş", of full speculation and complete illegalisation. It is considered a priori that, its perception changed in line with the above mentioned periods through which the phenomenon itself has materially and considerably changed.

\section{INTRODUCTION}

As the title emphasises, the aim of this paper is not to define the gecekondu phenomenon nor to describe its development through history, but to discuss and explore the way it is perceived and explained by public opinion according to transformations it underwent over time. Gecekondu studies always remained as a focus of interest as well as one of favourite and fruitful subjects in Turkish social and urban sciences literature.

Numerous papers, researches, articles and books have been produced and published in this field. Question of perception, however, longtime remained a neglected side of the phenomenon, which is relatively less considered in gecekondu studies. Although different views on subject matter are considered, academic approaches and opinions of mainstream press are referenced in a relatively more pronounced manner. Development of the gecekondu phenomenon is categorized here as the 'early squatting period of the 1940s to 1970s', 'the politization period of 1970s' and 'the post-1980 period till today'. The principal reason for adopting these historic categories is the a priori assumption which indicates 
that the perception of the gecekondu phenomenon has also changed, as the phenomenon itself changed over time. Gecekondus of İstanbul are significantly more pronounced and referenced here, since the case of İstanbul represents a more elaborate and colourful version of gecekondu history in Turkey. Besides, change and transformation of gecekondus of İstanbul whether physically or in meaning match the historic categories above, more than any other example in Turkey.

Gecekondu and illegal construction/urbanization has undergone different phases through its history. Perception of the gecekondu phenomenon as well as conceptual approaches to the subject changed, as important qualitative transformations were observed in illegal construction/ urbanization all through the corresponding period. The Gecekondu phenomenon is generally evaluated and considered within the framework of: housing and urban planning; rural exodus; modernization; social justice and the urban poor; and, social stratification and polarisation. It is also possible to describe the relation of gecekondus with cultural preferences of dominant social groups as a process of transformation from innocence, marginality and social victims, to uprising, threat and dominant rural culture. At least this is the way the subject is generally perceived by leading press and media.

The Centre-Perimeter Theory that hosts the concept of "dependent urbanisation" is probably among of most referenced theoretical explanations of squatters and also for the gecekondu. According to this theory, the gecekondu should be considered within the framework of international economic relations. Therefore, "it is a way of living and a type of settlement generated by labour that is not employed by a modernized sector in a country developing through imported technology" (Tekeli, 1977, 93). According to the theory, due to the gap of economic development level between countries of centre and those of perimeter, a population explosion emerges in perimeter countries. Then, gecekondu is also an outcome of articulation problems between the large part of urban labour and that of modernized urban communities in Turkey, as a perimeter country which lives a different urbanisation experience than developed countries. Here, gecekondu also represents a certain way of capitalism based upon limited capital, undeveloped simple technology and cheap labour (Şenyapıll, 1978, 41). Additionally, squatting is the physical reflection of division between bourgeoisie and feudal communities through urbanisation process and a general panorama of urbanisation of a developing perimeter country in a dependent capitalist process to centre countries (Kongar, 1982, 26-7) and is the outcome of two different social structures in the city. And once this process is activated it is almost impossible to stop or control.

Theoretical framework described by the School of Modernization and 'dualist' explanations are largely referenced and quoted in gecekondu studies as discussed here. Theoretical explanations about immigration by the School of Modernization underline a couple of reasons. They are difference of real wages between countryside and in urban centres; then probability to be employed in urban formal sector. However, the previous one is corrected later as the difference between expected levels of income (Ersoy, 1985, 10). According to the School of Modernization, immigration of dynamic parts of rural population who imitate and/or adopt western standards of consumption into major urban centres create a state of equilibrium in labour market and in spatial development whether in cities and in rural areas. This approach also equalizes cities and urbanization into 
modernization (Ersoy, 1985, 8). School of Modernization and particularly the discourse of 'dualist structure' is highly criticized by the School of Dependency since capital and labour movements are generated from periphery but not the centre in a way to consolidate income inequalities. In reality, dualist structure is the outcome of the same and only historical process (Ersoy, 1985, 11-2). Then newcomers do not wholly adopt the rules and values of the existing system as it is highly visible in case of gecekondu. Here 'articulation' looks more suitable than 'integration', since integration points transformation of a half into the other but articulation also means synthesis and division of labour (Ersoy, 1985, 17).

However, theoretical explanations about squatters are mostly of western origin. That's why they are also criticized since they represent western values and western point of view of urbanization. According to dualist approach squatters are a temporary degeneration of the system (Şenyapil,, $1978,10)$. Therefore, this degeneration should be and can be corrected and the system can be put in its previous 'normal' condition. Maybe one of the most important contributions of gecekondu studies into universal literature is that gecekondu or squatters are not a degeneration of the system but are the physical appearence or outcome of a more comprehensive social change. However, this approach is longtime limited to scholars and is not shared by public opinion and public authorities. As illustrated here through press news public opinion, public authorities and even a considerable part of intelligentsia longtime perceived gecekondus as a degeneration of modernist values and resisted them.

Turkey's post WWII urbanisation experience, which is largely influenced by squatting and rural exodus and urban areas which emerged through this process are mostly defined and described with adjectives such as "excessive", "deformed", "unhealthy", or "fake". This is well-known and very pronounced in Turkish gecekondu studies. Even in various approaches to the phenomenon and in proposals generated for urban problems it is possible to see traces of a vision underlined by such definitions. It is also possible to define discussions on urbanisation and the gecekondu in Turkey as mostly shaped by bourgeois views and values. Proposals on prevention and/or slowdown of urbanisation should be considered within this framework. Here, mostly argued and criticized are the new immigrants to cities and the rate of urbanisation beyond an 'acceptable' level. Even this discourse largely reflects reactions of middle and high income urban citizens (Okyay et al., 1975, 12).

In order to follow transformations in perception of the gecekondu phenomenon, definitions of gecekondu as a terminology by various social groups seem an appropriate starting point. Gecekondu is a popular term which first appeared with early gecekondus in the 1940s, literally meaning "landed by night" due to its very characteristics of the necessity of constructing all building illegally with limited resources in one night, before authorities would intervene. Gecekondu is a common definition on which all involved sides have consensus. But there is also some difference in definition of gecekondu due to the position of a particular social group. One of the earliest, genuine and most referenced official definitions of gecekondu is mentioned in a commission report of the Ministry of Reconstruction and Resettlement dated of 1962 (Gencay, 1962, 5). According to this report, the term gecekondu defines buildings that are; 1. Built on an occupied land; 2 . Constructed in a way that does not conform 
1. Article \#2 of Gecekondu Act of \#775 reads: "The terminology of (gecekondu) which is mentioned in this act, refers to buildings constructed independent of building and urban codes and on someone else's land without prior consent of its proprietor and public authorities".

2. Elected local administrator generally for a settlement of neighbourhood size.

3. Ümraniye is one of districts of İstanbul metropolitan area known for its large gecekondu settlements and gecekondu population.

4. Other officially mentioned reasons are: 'mechanization of agriculture, industrialisation, housing crisis, high rents, psychological reasons (?), insufficient municipal control and tolerance' (Gencay, 1962, 6-8). to building codes and regulations; 3 . Not td conform to hygiene and engineering rules; 4 . Constructed hastily.

This definition is to be repeated later in the Gecekondu Act of \#775 in 1966, with some minor changes (1). There are two important aspects to this definition: buildings should be constructed in a way that does not conform to building codes and regulations and the land on which it is built should be occupied illegally. This definition is adequate for the legal status of gecekondu, yet it has shortcomings in describing situations that generate gecekondu and some of its peculiarities. The way it is defined in terms of legal status and type of construction as prime criteria is a clear expression of a "modernist" vision based upon positive sciences. On the other hand, the other side of the problem puts a different definition of gecekondu. Mukhtars (2) of gecekondu neighbourhoods at the Ümraniye (3) district of İstanbul define gecekondu as one storey poor village houses with poor standards without any official land registers. This definition neglects gecekondus built on lands of shared properties (Erder, 1996, 65). This time, another research, also gives some useful clues to understand the difference in popular perception and meaning of gecekondu. This research conducted in Ankara in three settlements, in a gecekondu settlement, a newly developing apartment district and an established apartment district, reveals that gecekondu and apartment housing hold different meanings for their different types of residents. Therefore, perception and meaning of the gecekondu is highly relative according to the standpoint. As this research reveals;

"Gecekondu housing is perceived very positively by those rural migrants who are oriented to the rural community, particularly for the 'gecekondurooted' women who spend much of their time in the neighbourhood. This is so because of the way of life gecekondu housing provides, for example, close relationship with neighbours and spontaneous relationships with the outside. On the other hand, the association of gecekondu settlements with rural migrants in the larger society creates a very negative perception of gecekondu housing in the case of those rural migrants who are oriented to established urban society, particularly for young women ('younger modernizers')" (Erman, 1997, 91).

According to a description on which academic circles have a consensus, gecekondu is a kind of housing supply that emerged as a result of shortcomings in legal housing production for low income groups that migrated from countryside to large urban centres in Turkey following WWII (Tekeli, 1994). Shortcomings in housing production is also emphasized as the major reason of gecekondu phenomenon in early official gecekondu reports (Gencay, 1962, 7)(4). The role of housing shortage in gecekondu problem is repetitively accentuated and mentioned by scholars such as; "impossibility to meet housing shortage through normal (legal) production methods caused large masses of low income groups to solve this problem by themselves. This means housing shortage will almost all be met by gecekondus" (Keleş, 1983, 122). This definition basicaly puts a slant on the gecekondu issue that it is a type of housing supply for low income groups and this supply is realized through illegal methods. Therefore, it is at the same time "the spatial appearence of cultural and class differentiation" (Tekeli, 1971, 225; Şenyapıl1, 1981, 40-3). But gecekondu also means "cheap" labour who solve their problems almost without any cost for employer and government (Şenyapılı, 1981, 45). From the location point of view, gecekondu is a phenomenon that emerged around industral 
areas of large cities, generally located within their walking distance (Görgülü, 1993, 22).

Gecekondus also experienced major qualitative transformations through time. In a more descriptive manner, single-storey, simple but picturesque gecekondus with a garden of 1940s, 1950s or 1960s and multi-storey illegal housing units of post-1980 have not emerged within the same causal chain. One significant character of the gecekondu is its initial way of building. In most of its history, gecekondus are initially built up as single-storey houses of single or double rooms with simple materials, as technically expressed "built up without conformity to legal regulations and arrangements related to urban planning and buildings" in legal documents. However, this simplicity in materials and building techniques which are particularly valid for early periods of gecekondus should at the same time be considered a strong point for its dwellers since it provides its owners a considerable flexibility of planning by which a simple gecekondu may grow through time in size with additions and may even get a different physical shape such as multi-storey housing as needs change.

\section{INNOCENCE AND MARGINALITY}

The 1950s and 1960s are somehow perceived by many as years of innocence and marginality for gecekondus. Innocence and marginality are quite a convenient definition for gecekondus of post WWII to roughly 1970s. At this stage, there is no organizations to solve settlement and employment problems of newcomers as well as there is no opportunity to establish economical and social relations prior to immigration since there is not a sufficient accumulation of rural population in cities (Şenyapıl1, 1981, 43). During this period, gecekondus and their dwellers are economically, socially and culturally marginal, trying to survive in harsh living conditions and situated at the outskirts of big cities in terms of physical location. Through these conditions, they are trying to satisfy their needs for shelter (5).Therefore, gecekondus of innocence also represents spatial effects of promoting to a non-marginal economical status of gecekondu family particularly from 1950 to 1960 (Şenyapill, 1981, 45).

Even though gecekondus first appeared in Turkey in late 1930s (6), the major turning point from which they became a general phenomenon and a chronic problem are the years following the end of the Second World War. The end of the Second World War marks the beginning of an era of large scale radical social transformations in Turkey. Following the policies of economic development in equilibrium and political-social stability of the Early Republic Period of the 1920s and 1930s, and the years of stagnation and prudentialism of the Second World War, Turkey took pace into a totally different period of rapid social transformation. The whole system was now moving into a new point of equilibrium. Stable and stagnant urbanisation left its place to rapid and unequal urbanisation which has not reached its final stage even today. However, urban infrastructure as well as legal, administrative and financial means were far from coping with such rapid urbanisation at this very critical time of transformation.

As an example, the Governor of İstanbul declared in 1945 that the number of people in one housing unit was 10 (K1lınçaslan, 1981, 239). A municipal report of 1953 clarified that construction of some 30 to 40,000 houses were required in İstanbul in order to cope with housing shortage (Kılınçaslan, 1981, 240). All those figures underlined the reality that in addition to
5. Marginality is highly discussed in
gecekondu studies. As some experts indicated, the view that "gecekondu people is normally manpower of marginal sectors" should be changed since this may be only valid for the 1950s and particularly for the 17, 43).

6. According to a survey on the gecekondus of Ankara during the early 1960s, the oldest among gecekondu areas of Ankara go back to 1938 . The first wave of development in these areas occurs in 1950 and the second in 1960 (Ankara Esat, Çankaya ve Dikmen Gecekondulart- (Gecekondus of Esat, Çankaya and Dikmen in Ankara) İ.İ.B., 1965, 2). 
housing shortage in the city, there were also shortcomings in housing supply for the low income: if there were enough supply of housing for the low income, would there be construction of new gecekondus? This is a question which is out of concern of this paper. The public authorities had no mechanisms available to cope with and to control this new situation. The situation was very appropriate for providing convenient conditions and to seek a solution to "legitimate" needs through "innocent" means. Thereby, gecekondus began to spread around big cities, first on public, and then on lands of shared and private property.

Early gecekondus were generally in conditions which strengthen their innocence as well as their marginality. In most cases they were built from simple materials such as mud brick or wood, externally covered with tin in a way to provide minimum sheltering conditions. Roofs were also covered with tin or plastic sheets waterproofed with tar. Most of the construction materials were either collected or recycled. But this was a temporary situation. From 1950s onwards, gecekondus begin to improve significantly. While brick or cinder blocks replace mud brick in gecekondus which were still largely built with one room, credit for gecekondu dwellers in material trade also emerges. Then, expertise and professionalism naturally become involved in the gecekondu construction process as materials and construction methods change (Pulat, 1992, 141). By the time, as the number of gecekondus keeps on growing and the phenomenon spreads, a semifeudal patronage also emerges during the 1950s as another institutional part of the gecekondu phenomenon and as one of major results of this continuity and the tolerance by politicians.

During this period of innocence and marginality, gecekondus also play a major economic role in contrast to their marginality. Large masses easily find employment while migrating into large urban centres under the influence of industrialisation. First of all they offer cheap labour for the developing industry, capable to reproduce themselves easily due to their ability to solve problems by finding a solution for an important problem such as housing. Newcomers begin to build primitive huts on poorly controlled land around industries, hoping to find a job. Industries also contribute to the process even they do not clearly show their supports. They make advance payments to employees because this helps to keep wages low and stable (Şenyapil1, 1998, 302; 1985, 135). Because, there is a functional articulation between centre and periphery and production increase through the augmentation of periphery, labour as much as possible is more suitable for capital (Şenyapılı, 1981, 20-1). Gecekondu families also become good consumers for developing local industry goods particularly in 1960s (Şenyapıll, 1981, 47). All those reasons have a significant importance in tolerance and compromise in favour of gecekondus by political authorities. Indirect support and tolerance towards a cheap solution for a basic human need that falls under government responsibility should also be considered as a mean of an undeclared social policy.

The emergence of gecekondus obviously shocked and dissappointed the early idealist generation of intellectuals who shared the common image of an urbanized modern society. As early as in 1935 Yunus Nadi, a journalist and a well-known figure of Republican intelligentsia wrote about first gecekondus in Ankara as follows:

"It came to my mind while I was talking about Ankara, there we saw in confusion one day that on the mountain facing the old city, a city part from 
7. Yunus Nadi, 31 August 1935, in the daily Cumhuriyet.

8. Metin Toker, 28 September 1948, in the daily Cumhuriyet.

9. This series of interviews published between May, 13-25, 1949, in the daily Zafer, Ankara.
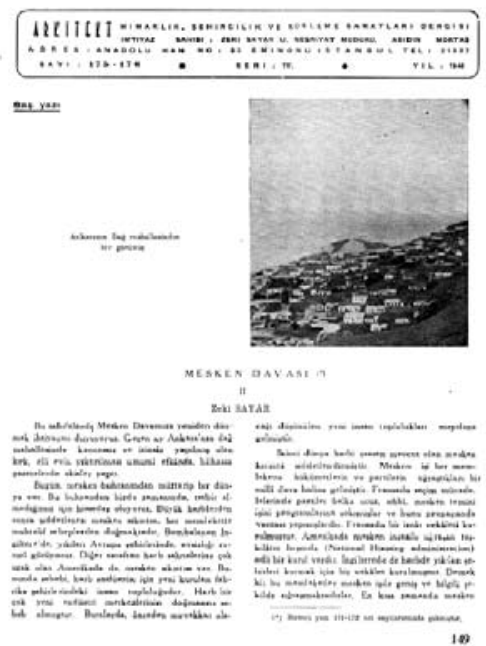

Figure 1. Since the very beginning, gecekondu has been perceived and explained within the frame of housing shortage. An early example of this perception from 1940's: Article entitled "The Housing Question" with a picture of famous Altındağ gecekondus in Ankara in the major architecture-urbanism magazine of the period. An intellectual of the period was complaining: "Now, there is an illegal town in Ankara! A whole town...a town which covers hills around the castle..." (Arkitekt, 1946) scrappy houses from bottom to top emerged without any warning, where this mountain next to the other city was a hilltop ready to be a forest. How to find a way to correct this mistake?" (7) (Tekeli, 1980, 91)

Another journalist and an eminent figure of Republican ideology Metin Toker, is writing in 1948 about "disgusting" and "horrible" neighbourhoods very close to select district of Şişli in İstanbul (8) (Şenyapılı, 1978, 52). Another figure Falih Rıfkı Atay, one of the leading early Republican intellectuals who also participated in the planning of Ankara, described in his memories early gecekondus in the city:

"A zone of cheap land for the homeless poor was reserved in the city plan. Land was free for everyone needing it. Even a small hut would be built under the supervision of an engineer. An area for public facilities such as schools, shops and health care was reserved at the centre. The Municipality did not mind this responsibility. Rural immigrants swiftly built gecekondus on the slopes around the Ankara Castle. The Urban Development Committee decided to eliminate them, and the city authority and municipality did not care. Well, this tragedy of the gecekondu in Turkey began at that time and went further due to Ankara Municipality's incompatible interferences to urban planning. Now, there is an illegal town in Ankara! A whole town.... town which covers hills around the castle... Even a pickpocket cannot escape from our police: but, a house, a block, a town can escape. Would you believe this? Whose shame? The people's? No, our urban planning practice is to blame! The reserve land for the poor and workers housing in the Ankara plan should have been acquired at that time for almost nothing and lots should have been offered to those who wanted a house and who had no means other than work. But we did not do it..." (Atay, 1969, 426-7).

Two significant points can be seen from this text: housing problem and disorder in planning discipline (Figure 1). These two reasons are valid to a large extent particularly for the early generation of gecekondus. But it is obviously not possible to explain the entire phenomena according to these two reasons. However, statements are particularly important since they represent the way the early generation of Republican intellectuals perceived the phenomenon. It is obvious that intellectuals of this generation perceived gecekondus as a clear threat to the modernist ideals of the Republic.

In 1949 Adviye Fenik, a journalist, published a series of interviews about gecekondus in Altındağ in Ankara (9):

"The neighbourhood is made of tin-covered huts and holes carved out on the soil. Tin barrels or large jars with a hole at the bottom and turned upside down are put over holes which are dug in regard of slope of the hill. These are windows as well as chimneys of "houses". The author sees many of these jars and tins around as she climbs the hill. There are sinks dug into the soil within homes. Rain water which runs downhill and penetrates into homes is collected in these sinks. There is no furniture in the houses. Toilets are common and dirty water runs over in the open. The author (Fenik) talks about forty thousand people who live in this condition. They work at marginal jobs and there exists no solidarity since they are extremely poor" (Şenyapıl1, 1985, 83).

This interview is highly interesting since it represents some qualities of a field survey and gives a vivid account and almost frightening description of a gecekondu neighbourhood and gecekondu life in its very beginning. No doubt it had created a concern and astonishment towards gecekondus in public opinion. Another interview on gecekondus of Ankara which is largely quoted in following pages will show that very few has changed in 
10. The narrative is originally mentioned in Nephan Saran's book of İstanbul'da Gecekondu Problemi (The Gecekondu Problem in İstanbul), Türkiye Coğrafi ve Sosyal Araştırmalar Merkezi, İstanbul, 1971.

11. Zeytinburnu, one of Turkey's early gecekondu areas, provides a typical account of gecekondus of the period of "innocence". First gecekondu in İstanbul appears in 1945 in Kazlıçeşme location of Zeytinburnu. During 1947-48 the number of gecekondus rises rapidly. In March 1949, there were 3,218 gecekondus out of some 5.000 of total İstanbul. In 1950, the Fatih District had 4,183 gecekondus including Zeytinburnu; the highest number in İstanbul at that time (Tekeli, 1994, 94-5). While Zeytinburnu has been acting almost as a school to 'discover' means and methods that would subsequently be followed by other gecekondu settlements of Turkey, it becomes aware of its need for social and political weight in order to be able to survive. Therefore, it rapidly progresses through the stages of urban development, reaching a neighbourhood size from a simple cluster of gecekondus, before attaining the size of a district and township (Akbulut, 2003 194). The population of Zeytinburnu also rises through immigration, reaching 50,000 in 1953, the year when it finally becomes a sub-district of Bakırköy. According to a newspaper in 1954, some 50,000 people got shelter in 18,000 gecekondus around Yedikule-Zeytinburnu zone (Kılınçaslan, 1981, 240). more than ten years since this one in terms of gecekondu life while physical conditions are a lot improved.

It seems also impossible to tell that even political authorities truly perceived and clearly understood the phenomenon during this period of innocence and marginality, as was understood in public opinion. It seems that a paradoxical and doubtful position was dominant in the public opinion along with the understanding of political authorities: there is no compromise on planned urban development and urban aesthetics of the modernist ideology, but on also, regarding social justice, and moreover, considering voting potentials of increasing gecekondus, the problem is ignored among daily compromise of practices and conduct without a significant plan and program. Aimed at winning the votes of increasing and encouraging gecekondus, politicians also practiced a variety of creative attitudes to legalize gecekondus through the 1950s. With the help of democratic means and experience, the gecekondu underwent a process through which it devloped its political power and organisational capacity. One interesting example of how gecekondus survived through many attempts to eliminate them and how they took advantage of political compromises and competitions is mentioned in Nephan Saran's book İstanbul'da Gecekondu Problemi (The Gecekondu Problem in İstanbul). The narrative includes some significant clues of how gecekondus were perceived by civil authorities and politicians in early stages. She narrates in 1971 how gecekondus around Zeytinburnu avoided demolitions in 1947 and 1948 as follows:

“Here (Zeytinburnu) first gecekondus were located along the road. In the beginning gendarmerie was surprised of this but as their number increased in time they were obliged to interfere and first the kaymakam (district governor) then the governor of İstanbul were informed about the situation. The governor attempted to demolish them, yet he did not succeed since politicians intervened. However, gecekondus were under siege with the order of the governor and even no water was supplied. Winter and spring of 1947 passed with disputes and quarrels between gendarmerie and gecekondu people. On a Tuesday in May 1948 the whole gecekondu area was warned in written and verbal way that gecekondus would be demolished the following Sunday. People were put in panic. While they consulted around to stop this, they were advised in a newspaper office to meet the President of the Turkish National Assembly (TBMM) who was coincidentally in İstanbul at the time. A group of leaders among gecekondu people visited the President in his residence and convinced him to come and visit the gecekondus. President of the Parliament was welcomed in Zeytinburnu by crying people in a desperate and miserable situation. Essentially the car of the President could not go further since roads of Zeytinburnu were covered with mud at the time. The President promised people that their homes would not be demolished and a few days later the radio announced that gecekondus would not be torn down" (10)(Gökçen, 2003, 182).

In 1940s the general perception and interpretation of the phenomenon is like a "disaster" which hit cities due to planlessness and imprudence of the government (Şenyapıl1, 1985, 86). In the beginning, in 1940s, the majority party CHP (Republican Popular Party) and its governor of İstanbul Lütfi Kirdar had made a clear choice to eliminate the "problem" from the system when small in size. However, this choice soon failed and was politically obsolete as illustrated above. Government resources used only to demolish gecekondus was also criticized in the Parliament within the majority group in 1947 (Şenyapılı, 1985, 86). On October 15th, 1949 the daily Cumhuriyet 


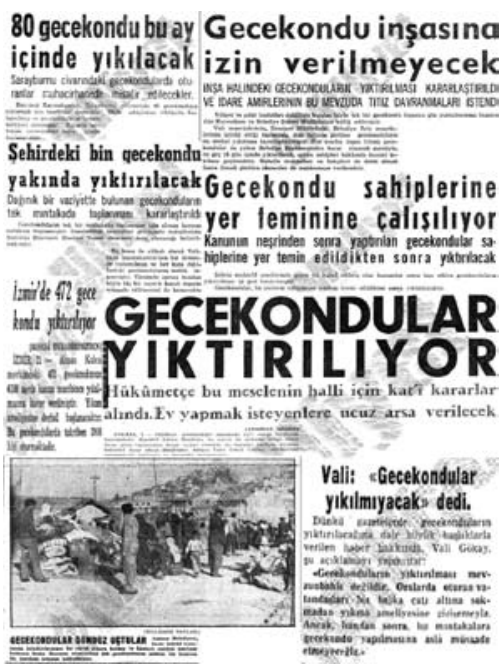

Figure 2. "80 gecekondus will be demolished this month", "No permission for gecekondu construction", "1000 gecekondus in the city will be demolished soon", "Land provision for gecekondu owners", "472 gecekondus in İzmir will be demolished", "Gecekondus will be demolished", and "Governor of İstanbul: "No demolitions" for gecekondus".

There was always a search for legal solutions to the problem within the framework of urbanism, while self-made practical solutions were put into operation. On the eve of the 1957 elections, news regarding gecekondu demolition appeared in dailys, while a short news from Governor of İstanbul signals giving up gecekondu demolitions. As found in gecekondu surveys, just before the 1950, 1954 and 1957 elections, the number of gecekondus increased considerably due to tolerance, lack of authority and political opportunism.
12. Number of buildings legally defined as gecekondu in İstanbul is: 8.239 in 1950, 40.000 in $1958,61.400$ in $1959,120.000$ in 1963 and around 195.000 in 1972 (Tekeli, 1994b; Şenyapılı, 1985, 142). It was assumed that $35 \%$ of İstanbul population was living in gecekondus in 1963 and \%65 in 1995. Number of gecekondus and size of gecekondu population in Turkey through years are as follows: 1955: 50.000 gecekondus and 250.000 people; 1960: 240.000

gecekondus, 1.200 .000 people; $1965: 430.000$ gecekondus and 2.150 .000 people; 1970 : 600.000 gecekondus and 3.000.000 people; 1980: 1.150.000 gecekondus and 5.700.000 people; 1983: 1.250.000 gecekondus, 6.250 .000 people. (Keleş, 1983, 196-7.) announced the halt of demolition of gecekondus. And in first of November 1949 the daily Hürriyet wrote about the visit of the governor of İstanbul in gecekondu areas, how he was welcomed by thousands of gecekondu inhabitants with flowers decoring his way (Şenyapıl1, 1978, 55). This changing attitude towards gecekondus would also be the subject of severe criticisms from modernist bourgeoisie. The day after the visit Metin Toker criticized this new attitude with humour and derision:
"The number of people who live in gecekondus reached thirty thousand.
The governor (F.K. Gökay) patronizes and protects gecekondu inhabitants. We have nothing to say for this. But we should not be surprised if gecekondus with their own laws, rules and councils today will have tomorrow their police forces and even an army" (Şenyapilı, 1978, 52).

On October 18th, 1956, Minister of Reconstruction organized a meeting of urban development in İstanbul. Just assigned for this duty a day before, he declared that it was unjust to study the gecekondu question without considering its economic and spatial aspects in a comprehensive way. $\mathrm{He}$ announced that the state-owned bank for housing credits would construct multi-storey apartment blocks instead of gecekondus (Şenyapılı, 1978, 62). This was a search for legal solutions to a problem within the framework of urbanism, while self-made practical solutions were put into operation. On the eve of the 1957 elections, Democrat Party (Demokrat Parti, DP) which held the majority, began to deliver title deeds in gecekondu areas through its local branches. According to newspapers of February 26th, 1957, 62 people were delivered title deeds by officials from the local branches of the DP at Zeytinburnu (11) (Şenyapıl1, 1978, 64). As supported by the findings of some gecekondu surveys later in 1960s, just before the 1950, 1954 and 1957 elections and following the Military Intervention of 1960, the number of gecekondus always increased considerably due to political tolerance and lack of authority (İ.I..B., 1965, 4). On the one hand, there was an ongoing quest to find legal solutions within traditional "urbanist" approaches while, on the other, simple solutions within daily practice motivated by political opportunities were on the way in the uncertain climate of urban politics (Figure 2).

Urban amnesty is obviously one of the most implemented among the formal practical solutions. Urban amnesties have always been one of major dynamics in support of gecekondus. A further 15 acts were legalised following the first amnesty law of 1948. Among these, the acts of 1949, 1953, 1963, 1966, 1976, 1981 and 1984 are more important. There were some 30,000 gecekondus in Turkey when the first amnesty became effective in 1948. At that time, almost 5000 gecekondus which make $1 / 6$ of Turkey's total are in İstanbul (12). Then, among others, the reason for the 1976 Amnesty is quite interesting: "In spite of amnesties for almost every kind of crimes due to the 50th Anniversary of the Republic in 1973, gecekondus are excluded." From 10,000 in 1940 the number of gecekondus reached 1.5 million on the eve of the 1984 Amnesty according to Prime Minister of the time Turgut Özal.

It seems more realistic to see urban amnesties as a conscious policy than an administrative inadequacy. This is particularly valid for the 1980 one and the more recent ones, where even large-scale destruction and clearences have almost no overall effect upon the phenomenon at all. Urban amnesties were never introduced to prevent gecekondus nor to control them, but only resulted in providing and strenghtening a more legitimate basis for gecekondus. Two amnesty laws legalized during the 1980s fall quite 
13. Indeed, the total number of gecekondus in Turkey was estimated to be some 1.5 million at the time, and applications to "Special Technical Offices" to obtain a "Land Assignment Title" (a temporary land title), which was the major novelty of the Amnesty Law, remained in very limited numbers: 119,500 in 1984 and around 100,000 in 1985.

14. Ankara'da 158 Gecekondu Hakkında Monografi, (A Monographical Study on 158 Gecekondus in Ankara). apart in their aims and in practice compared with the previous ones. When the Amnesty Act of 1981 became effective, there were some 400000 gecekondus in Ankara, although only 196000 did benefit from the act. Among them, only a limited number of 61000 were authentic gecekondus, the rest being illegal buildings of various types and uses. As an official expert declared for the Amnesty Act of 1984, "this meant to legalize illegal construction and illegal industrial buildings" (Uysal, 1985) (13).

Around 1960s, first empiricial surveys about gecekondus began to appear in Turkey. This led to a highly productive period in terms of scientific research on the gecekondu phenomenon in the following decade. Some research and surveys are of considerable value on documentation of the gecekondu phenomenon, and socio-physical conditions at the early stages are highly rendered as research examles of this period. The Institute of Resettlement and Urbanism at the Ankara University established in 1953 published a report entitled "A Monography about 158 Gecekondus in Ankara" in 1957 (14). The research has a particular importance in Turkey since it represents the first monographical work about gecekondus based on comprehensive household survey and interviews (Keleş, 1986, 273). From 1950s onwards foreign experts also contributed to the field to some degree, mostly in the form of reports based on limited empirical studies. Among others, there are also leading figures, leaving more important traces that are worth to mention. Charles Abrams, who is particularly well-known as an international housing expert during 1950s and 1960s on problems of low-income groups, travelled in Turkey and made observations on gecekondus during the 1950s. He proposed legalisation and standardization the way gecekondus were built, as concluding his research. He claimed;

"Some of the better squatter houses in Ankara and İstanbul suggests one the presence of a group of workers with a natural aptitude for building. Since many of the houses are built of mud brick, and rocks collected nearby, or of scrap wood and tin, to be erected in less than twenty-four hours to avoid public interference, one could not help acquiring a sincere respect for these people... Yet a good development might have emerged, given some initial planning regarding streets and infrastructure of the settlements, and with somewhat better materials, more time to build, some intelligent supervision, and assurances of security of tenure" (Abrams, 1964, 201).

However, as he cited among his memories for his experience in Turkey in 1950s, he mentioned that "his proposals, like any other report of similar foreign experts or missions, would not have any influence on the rigid bureaucracy, similar to a mosquito bite on an aircraft carrier" (Abrams, 1964, 202). As a matter of fact, similar reports and proposals did not have considerable influence on the bureaucracy which was followers of an orthodox modernism.

Housing problem, illegal and unplanned urbanisation, gecekondus and urban planning in general were major areas of urban studies between 1950 and 1960 in Turkey. Descriptive monographs, particularly with reports on the housing problem were more common methods of dealing with the abovementioned subjects. With the exception of certain reports, studies of this period generally deal with the problem in a popular manner as perceived by the public, and only a few attempts to tackle problems within the context of social transformation (Keleş, 1986, 281).

In 1960s urban problems inherited from the previous decade kept on growing and sometimes they became more dramatic. Rural exodus 
accompanied with the mechanical character of conventional urban development plans which are far enough to solve new kind of problems only worsened the situation throughout the 1950s. By $196021 \%$ of İstanbul's population and 45\% of Ankara's population were living in gecekondus. In 1965 the share of gecekondus within total urban population reaches $21.8 \%$ (İnankul, 1990, 16). In order to cope with a worsening situation of urban problems, regional planning is adopted as a useful solution from late 1950s. Regional planning attracted considerable interest among scholars through the 1960s, while it had a limited degree of influence over politicians. In the First Five Year Development Plan, which became operational in 1963, an undirect approach to urban problems was adopted through the policies of regional planning, rural planning and development, immigration control, prevention of inequal development among different regions while, direct interventions and policies to urban problems are neglected. This approach is obviously influenced from similar trends and practices in the West. One of major novelties of the period in urban planning is planning at metropolitan scale. Metropolitan Planning Offices first in 1966 in İstanbul, then in the two other metropolitan cities of Ankara and İzmir, were established respectively in 1968 and 1969. They were under the Ministry of Resettlement and Reconstruction; but trends changed quickly in time, and a more urban approach was adopted in the Second Five Years Development Plan, from 1968 onwards. General approach of this plan was based upon the causal relationships between urbanisation-industrialisation-economic development and agricultural modernisation-industrialisation which were considered as prime factors of urban development and urban problems.

The Ministry of Resettlement and Reconstruction established in 1958 due to Turkey's growing urban problems, remained one of primal focal points in shaping of modernist thoughts and urban policies until its abolishment in the 1980s. Even the title of the "Committee of the Gecekondu Problem", established in early 1960s within the Ministry, is a good example for this modernist approach. Gecekondu was continuously perceived as a problem and a challenge for modernist urban ideals in particular, since transformation of the gecekondu from innocence to an illegal and speculative urban phenomenon provided sufficient reasons to support these doubts. Through the Ministry of Resettlement and Reconstruction, plenty of field surveys and research were realized during 1960s, and the outcome generated some general policies. It seemed that the bureaucracy and staff of the Ministry perceived gecekondus basicly as a problem of housing, and a cause of unplanned urbanisation. Every year 12.000 gecekondus were required to be listed for elimination in the First Five Years Development Plan. This amount should be naturally considered within total housing deficit. The Second Five Years Development Plan of 1968-1973 adopted the policy that every year a limited number of 7.500 gecekondus should be eliminated while half of the rest is proposed for improvement and the other half for clearence within 30 years (İnankul, 1990, 16-7). Major policy tools of bureaucracy of the period with regards to gecekondus were: the Gecekondu Act of 1966, Gecekondu Prevention Zones and public housing projects proposed by this act. Even though the Gecekondu Act does not mark a fresh beginning in perception of the gecekondu by the state, it somehow represents a positive step forward. Reform, improvement, elimination, and prevention were major aims of the act. Gecekondu Prevention Zones as an important novelty of the act were aimed at preventing gecekondus through healthy and comfortable housing 
MIMARLAR YAYLIM ATESIACTI

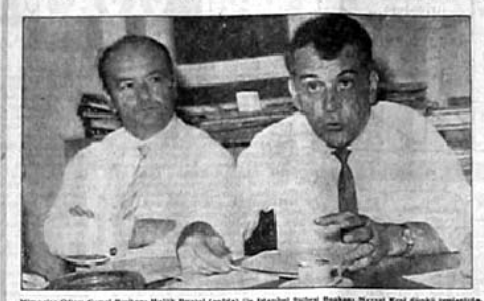

"GECEKONDULARA TAPU DAGGTMAK MIZaHTIR,

Figure 3. "Distribution of title deeds for gecekondus is an example for humour anthologies." In spite of policy novelties, the Gecekondu Act of 1966 was not satisfactory particularly for professionals. Legalization and distribution of title deeds to gecekondus was one major target of criticism, as declared ironically by the President of Chamber of Architects; (Milliyet, July 1966).
15. Milliyet, July 1, 1966: “40,000 Gecekondus are Provided Electricity and Running Water"

16. Milliyet, July 18, 1966: “Distribution of Title Deeds to Gecekondus is Humourous". provision by creating modern housing environments on state owned land. They were for rent initially, and for sale to gecekondu dwellers and low income groups in the long-run. Some press news of those days reflects this positive climate of the period towards gecekondus, through the Gecekondu Act. One of the leading newspapers announces new service provisions for gecekondus in İstanbul through words of the Minister of Resettlement and Housing of the period as follows:
"Twenty thousand gecekondus will possess electricity and another 20 thousands tha running water. The Minister of Resettlement and Housing declared that, 650 thousands inhabitants live in 130 thousand gecekondus, 80 thousand of which lack electricity and another 80 thousand, running water. In İstanbul the district of Sağmalcilar and Sinekli on the Asian side will be provided electricity and running water as pilot areas. The Ministry has reserved 22 millions liras for 1280 units of houses in multi storey blocks, to be built in Osmaniye Gecekondu Prevention Zone. The school in this housing estate will be provided by the local governorship and shopping and other public facilities by the municipality. These housing units are to accomodate inhabitants of gecekondus in historic areas" (15).

However, popular solutions to the gecekondu problem by right wing politicians were always criticized by intellectuals and professional organizations, of which, the Gecekondu Act of 1966 was an example. Political measures such as the legalization of gecekondus through distribution of title deeds, was one of the major target of critics. Press conferences organized by local branches of the Chamber of Architects prior to approbation at the Parliament illustrated a typical major theme and a point for critics (16). The Chamber of Architects attacked the draft of the Gecekondu Act in press conferences organized in three cities (Figure 3). However, architects from İzmir argued that gecekondus were a proof of economic development. In press conference in İstanbul, President of the Chamber of Architects criticized the draft of Gecekondu Act and declared that "distribution of title deeds to gecekondus is an example for humour anthologies. He also accentuated inadequacies of the Gecekondu Act and underlined the importance of considering it within the context of "gecekondu-housing-urbanization-development plans" for the national economic development in equilibrium. He added that gecekondu population had reached $60 \%$ of the urban population in Ankara and $45 \%$ in İstanbul and Adana, were it was 33\% for İzmir. The total population living in gecekondus would reach a total of 12,5 millions in 1977, a more than half of the 21 million of total urban population at that time. According to the Development Plan, a total of 208.853 housing units should have been built in urban and rural areas in 1964, whereas the shortage was 87.423 due to decrease in housing investments. He pointed that the general settlement policy was in defects in Turkey hence, in spite of 45 thousand neglected villages, distribution of title deeds to gecekondus would only result with political investment. On the other hand, the General Secretary of the Chamber of Architects declared that ten years later we would have to live in shelters instead of houses and insisted on the importance of adopting social housing policies. However, local branch of the Chamber of Architects in İzmir commented that the increase in gecekondu construction is a matter of pride, indicating economic development in Turkey."

One interesting feature illustrated in these communications is the quite different point of views shared among different branches. Among the criticisms of the Chamber of Architects, which are mostly based on the mainstream left wing approaches, the last is highly interesting as it 
represents a different opinion reflecting a quite controversial approach only expressed and adopted by a handful of scholars: the direct relation of gecekondu and economic development, that gives a share of national pride, where the mainstream tone wold be concentrated on social policies. As an a priori approach was visible among critics to emphasize the temporality of gecekondus, any attempt to legalize gecekondus as a concrete part of the system should have been criticized and avoided.

However, the perception of gecekondu solely as a housing problem constituted to be a problem itself. The attempt at a good opinion did not arrive at targeted solutions since the basic desire of property ownership was not considered within the policy; the land speculation dimension of the problem along with the need for shelter was always avoided. Another notable part of the act was the Gecekondu Fund. The Fund was supposed to be an additional financial resource for physical and public service improvements in gecekondu areas. A considerable number of multistorey block apartment houses were produced for low income groups in Gecekondu Prevention Zones and similar areas until the 1980s. It is difficult to admit that generally good quality housing units and environments were created through these policies. Qualitative as well as quantitative insufficiencies of the Gecekondu Prevention Zones, and the social housing built by the state, in order to prevent gecekondus as well as to create qualified living environments, later become one of the major proofs for the inadequacy of this approach. Gecekondu Prevention Zones and similar policies were later harshly criticized by a variety of critics. As pointed out below in a quite interesting perspective, “...buildings called social housing nowadays, look like military barracks, and they also provide, as has been pointed on several occasions before, a threat for moral values" (Tuna, 1977, 11). There were many others criticizing the social housing through different perspectives. Finally, they all came to an end with the Urban Development Act of 1985, when the land of Gecekondu Prevention Zones were transferred to municipalities.

As mentioned earlier, during the 1960s there is the dominance of field surveys and empirical research in the field of gecekondu studies. During

Figure 4. During early years of gecekondu, there was almost a general and exaggerated perception of gecekondu areas among "urban" people known as "wild" areas full of unknowns. The popular weekly "Hayat" announces in 1960, a series of interviews by reporters who spent 45-days in a gecekondu. "I lived in Taşlitarla a month and a half" was the title of the series, with a flavour comparable to essays about exotic corners of the world, found in magazines of popular travel; (Hayat, 1960).

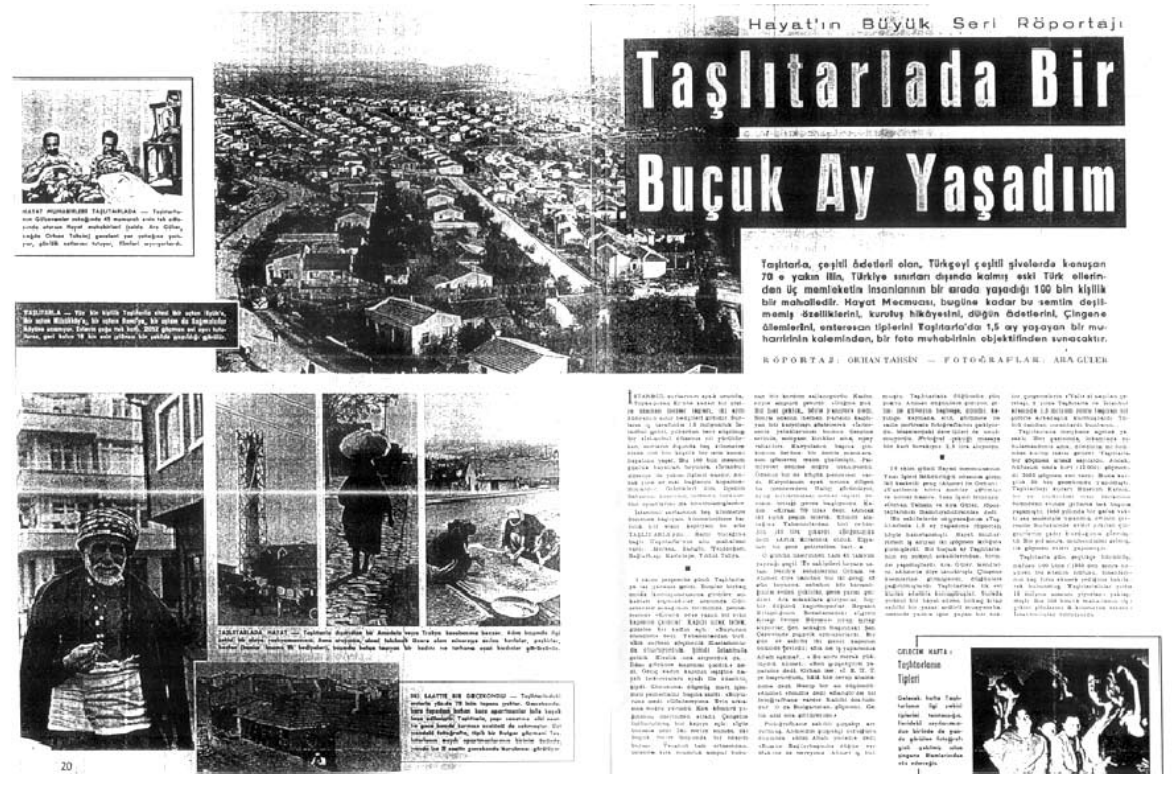


17. Field surveys of Ankara gecekondus took place during October-November 1963 and June 1964, and aimed to observe changes within a six-month period,

18. Under the original title of Ereğli: Ağır Sanayi Öncesi Bir Sahil Kasabası, Kiray (1964).
1963-64, the Ministry of Resettlement and Reconstruction undertook and published a series of monographs and field surveys based upon interviews in gecekondu areas of Ankara (17)(Figure 4). These field surveys were the largest and most comprehensive gecekondu surveys of the 1960s. The research on Ankara gecekondus (1966) of İbrahim Yasa from the Faculty of Political Sciences of Ankara University also took its place among others as the first and the most comprehensive field survey of social content (Şenyapilı, 1986, 290). The State Planning Organisation (SPO, DPT) also supported many important urban researches as being one of the major institutional bodies of national and regional planning during the 1960s. The research of Ereğli, A Seaside Town Prior to Heavy Industry (18) commissioned by the SPO to leading Turkish sociologist Mübeccel B. Kıray, became the first important urban sociological work and monograph in Turkey, even though it was not directly related to the gecekondu. The Anthropology and Ethnology Department of the İstanbul University, established in 1961 also contributed largely in gecekondu surveys in qualitative and quantitative terms. These works provided a systematic inventory of the gecekondu environment of this period (Şenyapıl1, 1986, 291). During the second half of the 1960s, under the direction of well-known Turkish geographer Erol Tümertekin and the Institute of Geography of the same university carried out a series of human and urban geography studies, in which gecekondus had an important role. One of big novelties of the 1960s in Turkey concerning urban problems was the start of urban planning and management programs in universities at graduate and undergraduate levels. In addition to the existing Institute of Urbanism and Resettlement (Şehircilik ve İskan Enstitüsü) at Ankara University and a couple of courses of urbanism in some other schools, the number and variety of issues in academic programs concerned with urban problems and urban planning increased from 1960s on, along with the way Turkey approached and perceived the problem. The influence and dominance of Turkish academic circles on gecekondu research undoubtedly began with this process from the 1960s onwards.

One of the most important changes brought by gecekondu researches into the perception of the problem is to consider gecekondu within the context of rural migration and rapid urbanisation. This was a new approach to the phenomenon. As the context of gecekondu researches changed, scope of surveys and gecekondu monographies began to focus on particular issues about migration and social change, asking what really changed, the way they change and the speed of change (Akkayan, 1979, 251).

Therefore, ahead of an old perception solely based on housing issues, now it began to consider and discuss gecekondus in relation to migration, rapid urbanisation, modernisation and economic development. The search for solutions to gecekondu and rapid urbanisation problems also took part in empirical studies and field surveys of this period (Şenyapıl1, 1986, 293). One of the earliest and the most comprehensive work on gecekondus, Charles W. M. Hart and Nephan Saran's famous survey of Zeytinburnu gecekondus in İstanbul during early 1960s, is a good example of this changing views and attitudes. As partly quoted below, it successfully formulated basic characteristics of the gecekondu phenomenon and problem clearly not only for professionals or decision makers, but also for simple people:

"Four thousand out of 9.280 people in families interviewed are working in factories. If these four thousand people had not migrated, who would be doing the jobs they did? We preferred to express this phenomenon as clear 
Figure 5. Through the 1960s, gecekondus attracted more attention, and many accounts, surveys and articles about gecekondus appeared. In 1962, an instructor's impressions of a gecekondu neighbourhood in Ankara under the title of "Gecekondus, Home of Misery"in a leading newspaper, gives a vivid account of a gecekondu neighbourhood, and illustrates another example of image of gecekondus among intellectuals with mainstream approaches of the period; (Milliyet, November 1962).
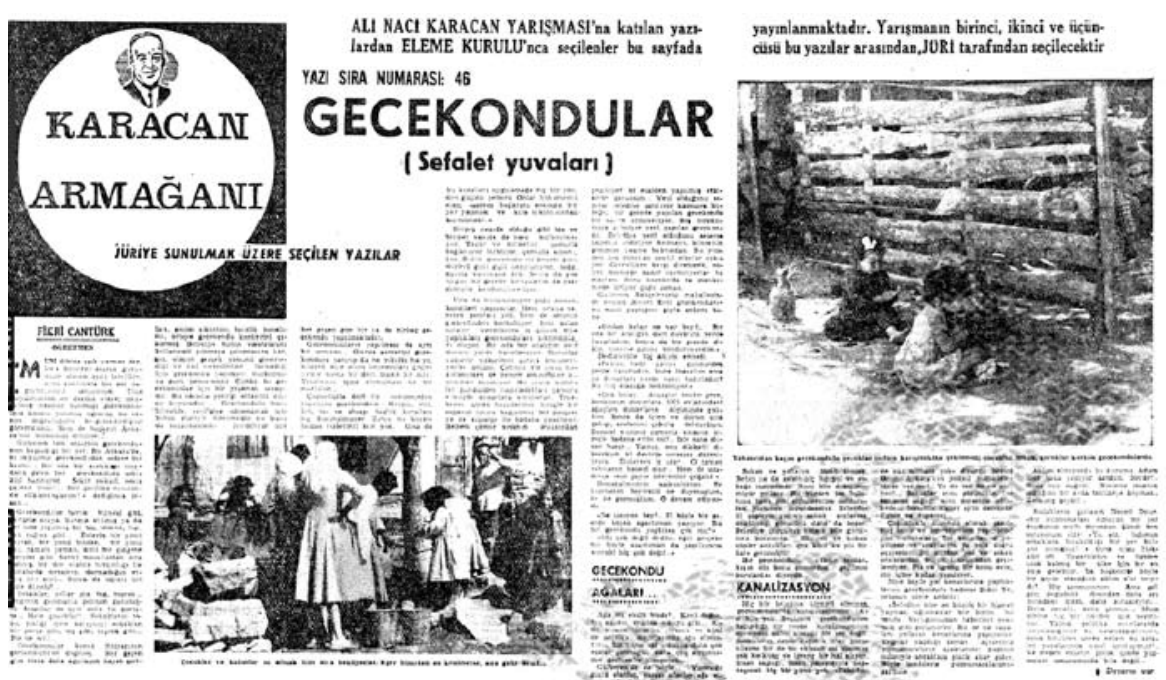

and as simple as possible. Most people did not accept to see the reality... Newcomers begun to build their homes in fields around Zeytinburnu after 1947, and they still continue to do today in 1968. Thus 125.000 people are living in this area. They found their jobs by themselves without any assistance from the government, and as they built their houses in the city without any support from the government, even in spite of the oppression and opposition from the government. Is there any other choice for housing for them, other than gecekondu ? Who will build houses for them if they did not build gecekondus? The answer is simply no one... The most important outcome of our work is that gecekondus are permanent, and they will last in their places and, gecekondus should be considered as an original solution of the Turkish people to meet the housing need of working class ..." (19) (Hart, Saran, 1969, 100-1).

It seems that the general reaction of public opinion towards early gecekondus was almost paradoxical. There was compassion in public opinion. But at the same time an attitude full of anger on different levels was also gaining ground because of the disturbance due to the spread of gecekondus. This disturbance was basicly due to degeneration of an urban life and order. It seems possible to suggest that there was a perception of gecekondu neighbourhoods among ordinary people as even "wild" areas full of unknowns. For example, one of the era's popular magazines, the weekly Hayat published in 1960 a reportage by the two reporters who spent 45-days in a one room gecekondu, rented under the guise of newly-arrived migrants, which had the flavour of articles to be found in magazines such as Life, Paris-Match or National Geographic, about strange tribes in an exotic, remote corner of the world (Figure 5):

"Taşlıtarla is a settlement of 100 thousand inhabitants with different traditions, where various dialects of Turkish are spoken by those gathered here from every corner of Turkey, as well as from ancient lands of the Ottomans now lying beyond modern Turkey. The Hayat weekly will show you characteristics that have remained unexploited until now, a story of foundation, marriage traditions, gypsy entertainments, and the eccentric characters of this settlement through the eyes and camera of two reporters who lived there for a month and a half"(Tahsin and Güler, 1960). [The article begins as follows]: "At the foot of the walls of İstanbul, the grave stones from Topkapı to Eyüp are like guards of two separate worlds. Within the walls, while the city of İstanbul of 1.5 millions continues its familiar "İstanbul routine", another city of 100 thousands lives its own life beyond
19. Hart and Saran (1969). Surveys conducted
by Charles Hart, who was Head of Social Anthropology Department of the Faculty of Literature in İstanbul University at the time, had firstly begun in 1962, on the Zeytinburnu gecekondus that included areas of Gültepe, Çă̆layan and Kuștepe. Hart's research was supported by İstanbul Chamber of Commerce, İstanbul Municipality and the Ministry of Housing and Resettlement. A report (Zeytinburnu Report) of this comprehensive research was later published. 
Figure 6, 7. Two posters for the play of "Keşanlı Ali Destanı" (The Legend of Ali of Keşan; 1964). The well-known masterpiece of Turkish cabaret theater is a narrative on early gecekondus, original in many respects, and rich in humanism, written by the reknown Turkish writer Haldun Taner. The work provided a vivid and impressionistic description of gecekondus in the era of innocence and marginality within a social and physical context, and was also adapted for cinema. The story was inspired by a real person from Ankara's famous gecekondu area of Altındağ in early 1950s.
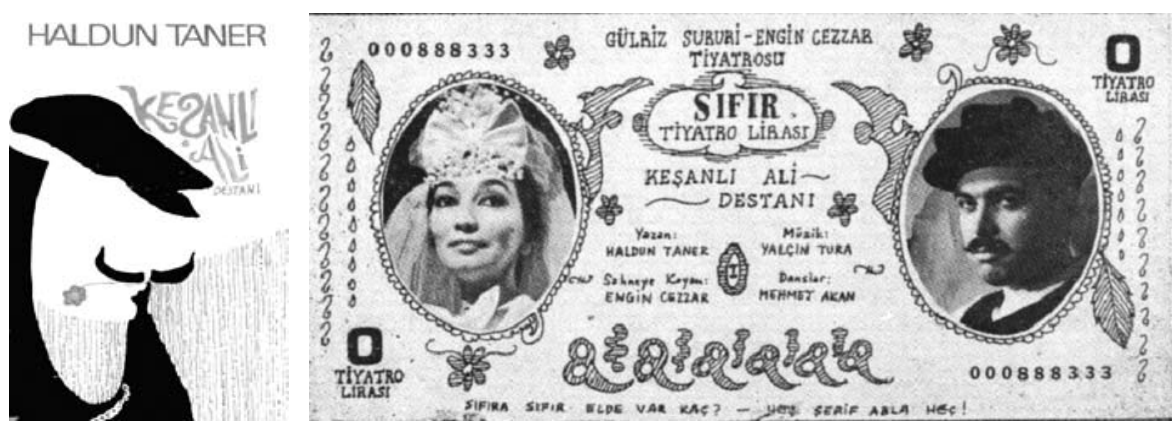

the walls... Taşlitarla was a site of foreign migrant people. However, only one tenth $(12,000)$ of them are foreign. There were 2,052 houses built by the state for immigrants from abroad. In contrast, 20,000 gecekondus were built. Hüseyin Kansız, who founded Taşlitarla, has lived alone for years in his home looking down the little lake of Sarıgöl. He woke up one morning in 1950 to the sounds of music and saw gypsies whose houses in Sulukule within the city walls had been expropriated, and they put tents around his house. One year later engineers arrived and built up the first houses for migrants. By the time Taşlitarla expanded, and reached around 100 thousand people. The population of the city particularly increased after 1955, and it was determined through the total units of bread consumption; where the inhabitants of Taşlitarla came to consume 18 million units of bread every year. An interesting characteristic of this settlement of 100,000 is that, it is unknown to those living in İstanbul 5 km away" (Tahsin, Güler, 1960).

Through the 1960s gecekondus will gather more and more attention and interest. Many accounts, surveys and articles about gecekondus and gecekondu life appear in the pages of press. In 1962, an article based on an interview and observations published in a leading newspaper also gives a vivid account of a gecekondu neighbourhood in Ankara through eyes of an instructor. This account illustrates another good example of perception of gecekondus by intellectuals with mainstream approaches of the period. Even the writing style and the language of this account which was titled "Gecekondus, Home of Misery" reflect the popular understanding of gecekondus particularly among intellectuals and urban population of $1960 \mathrm{~s}$ (Figure 6). The article begins with a mainstream general description of Gülveren Mahallesi, a gecekondu area in Ankara, with some general and stereotypical observations about gecekondus. Here as illustrated in the text below, an emotional popular narrative is highly significant with particular emphasis on words which strengten the perception of a deprived physical space and unfavorable living conditions such as "misery, miserable, dirty, dust" (20):

“...Gülveren is a place of eight thousand gecekondus. This is just a part of two hundred thousand gecekondus in Ankara... Each gecekondu holds a room and an entrance, houses eight persons. Eight miserable and desperate people!... People we call "Citizens!..." in political terms... Gecekondus are like chicken sheds, haphazardly thrown here and there, like a chunk of stone, tin and soil piled one over another... One side of houses is soil, another of tin, the other of stone; like a dirty patchwork bundle... Streets, roads are full of dirt, dust and clay... Scattered and miserable looking. Above all, children?... Merged into the dust and dirt of streets; like a piece of street, like a stone, like soil... Dirty and miserable!... Gecekondus are born from constraints and obligations of the need for shelter. Conditions of living which gets harder day by day, rising cost of life, and unemployment gave birth to cities of gecekondu. Even municipalities tried to eliminate them by all means, but they did not succeed, since reality is not well understood. This 
is a struggle for survival with gecekondus. Defeat in this struggle means the deep misery... Very conscious of this people of gecekondu is resist with by means for not to get defated but to succeed."

The text continues with similar narrative but now focusing on various aspects of gecekondus and gecekondu life:

“Gecekondus are mostly built up with four materials: Mud brick, cheap brick, stone and wood. Hygiene is neglected. They even know nothing about this. What is important for them is "only to build a shelter and not to pay rent !.. Mortar is not used in stone buildings. Stones and bricks are joined with each other and plastered with mud. All materials are prepared secretly during daytime. Then the gecekondu is built in a convenient nighttime with the help of neighbours. In most of cases, skill and expertise are not used. They can not pay for a master and they are also afraid if the master informs the authorities. Sometimes jobless masters help the demolition of gecekondus they built in order to create jobs. Those who have a strong fist or who have money become landlords of poor gecekondu houses... This is almost a rule. Where there is poor people, there is a landlord;... Leery landlords hold state owned lands with tyranny. They even divide lands into plots (!...) People who build gecekondu is aware of this but has to pay for this land since they have no means to pay for a rent.. Families are crowded with children. These lands are also cheap. They desperately buy them...

A plot of two hundred square meters costs five hundreds liras at least and this goes up to two thousands liras. That's what a landlord can get. An owner told: "The land costs two thousand, another two thousand is for the gecekondu, and that makes a sum of four thousand. This is at least enough for a shelter. The amount is paid in cash, saved through years. Sometimes even the money is not sufficient: the landlord should approve the buyer. If the landlord does not approve, there is no way to build a house. The landlord can spy alerting the municipality to provide demolition of the gecekondu. This is the first type for landlords.

There are landlords after earining easy money. They build gecekondus as much as they can. Today in Gülveren there are landlords who own more than fifty gecekondus. A local man was complaining of a landlord of this kind: "He has forty to fifty gecekondus. Besides he robs us by selling wood as timber. We buy from him because he sells by credit. He also cheats the municipality like he builds a school. Then he rents his gecekondus to poor people room by room from sixty liras. We also worked during construction since we were afraid." Gecekondus are rented to fifty liras per month at least. There are gecekondus rented to fifteen hundreds. A landlord with fifty gecekondus gets approximately two thousand five hundred a month. Without doing any work. This is the second type of landlord.

There are also "landlords of protection". Tough, ruthess, shameless. They patrol neigbourhoods all day long either themselves or with gangs. Wherever there is a gecekondu construction, they are present on that site. They ask for bribe not to inform the authorities. In most cases gecekondu owner pays the money. Even, the protective behaviour should be paid prior to the construction. This is called "hush money". On a 'quiet day' at least two or three gecekondus are built. Not less than a hundred liras is required for a gecekondu. One can guess the amount of a monthly revenue. This is the third type of the landlord.

Gecekondu which was born of need of shelter served for the good of these three types of landlords. They exploit conditions which were born of necessity. These parasites do nothing to provide some service to gecekondu neigbourhoods. Municipality who has no tolerance to a poor family avoids gecekondu landlords."

The text then makes a brief account of infrastructure with similar narrative accents of poverty and unfavorable conditions: 
"Irregular open areas left between houses and neigbourhoods are called roads and streets. Most of them are not suitable even for a horse-drawn cart. Due to narrowness, dirtiness and the bad condition, no taxi driver wants to go Gülveren. There is no road or street covered with concrete or macadam. That's why you have to breathe dust clouds while you walk. Disposal of garbage into streets and vacant lands only worsen the situation. Garbage collectors and street sweepers of the municipality do not even appear in the streets... "One can not walk here because of dust in summertime and of mud in winter," a gecekondu resident is saying... There is no trace of sewage in gecekondu areas where there exists municipal services... In an area where there are eight thousands gecekondus, there is no sewage. The general appearence becomes even more miserable and dirty when this is added to scattered streets... Toilets are mostly made of irregularly joined wood and tins. They are built next to streets... Bad smell spread into houses. A gecekondu dweller explains: “Municipality does not provide any service to us. We build them next to streets. When it rains, we let drains into streets so it runs with the rain. This is the way we clean toilets"... Water also is not enough in gecekondus. Gecekondu dwellers suffer from water shortage. "Three, four o'clock early in the morning, people run to the public fountain with their tinmade water pans... For a place in the queue, women begin to fight with each other. Meanwhile, water runs short. Then no water, no fight..." There are only five public fountains in such a large gecekondu area. On the other hand, just a few houses have running water. Sometimes water does not run for days and days. To get water from public fountains which run for only a couple of hours a day, is like to be victorious in a war. Yet who cares about tear drops... But the Municipality is senseless like a wall in front of this lack of water..."

The text then focuses on living conditions and livelihood of gecekondu dwellers:

"...the livelihood means money for the daily ratio in gecekondus... These people who came from different corners of Anatolia did not find what they expected, are disappointed and hopelessly clustered in homes of misery. This adventure they begin with a hope of better living, now continues in homes of misery in a different way. Misery did not leave them and destiny won over them here also... Now they suffer in pain of misery and defeat... Every kind of poor professionals can be seen here. Low rank civil servants, drivers, employees, porters, construction workers make the majority. There are also those who are occupied with cow stockfarming, second hand clothes sellers, street cleaners and watchmen. They have to take care of an average of eight people. Monthly incomes of low rank employees and drivers change from 300 to 450 liras. They are the better ones around gecekondus... Conditions of temporary workers are the worst. They work in constructions, road works and manpower needing works of private employers. There are also a lot of porters. Daily incomes change from 3 to 10 liras. They are jobless until they find a job for a month. Their clothes are extremely worn out. A porter says with eyes in tears: "My all asset is this rop sir...I take care of eight people with this... Many nights my children sleep hungry..." Poverty is everywhere... Famine, lack of water, dirtiness rule here like a king... Even the famine... For the time being the whole sttruggle is with it...

Morning, breakfast tea and bread... Many days they even can't find tea. Olives and cheese are for festivity days. Or only for serving precious guests... Lunch, grape and bread... Diners are mostly of boiled wheat and haricot bean... Many families say they can not eat fresh vegetables and fruits even we are in mid August... Above all fruits... It is like a charming friend, it may knock their doors or not... Fruits are purchased not as nutrition good but as an appetizer to consume sometimes, or to quiet crying children. Many gecekondu families did not leave ties with their villages. They bring foods for winter from villages. In gecekondus nutrition is unsufficient and very bad. That's why people are tired and weary... Malnutiriton is clearly visible 
in children. Faces are pale, weak and joyless... There is no healthy, vivacious child in gecekondus. They are stagnant and weary like oldman's... They even play in wall shadows quietly. They do not behave to their ages...There are various illness. İllness such as cold, influenza, bronchitis are of daily routine...Dirt of streets is the children playground. Hence, children's health is always under threat...Gecekondus also threaten public health of Ankara. A disease can easily spread..."

The text also comments on various aspects and some basic problems of gecekondu life:

"There is no park, nor playgrounds in Gülveren. Children play in dust and dirt of streets. They do not have any of their contemporates posses. They play by themselves in wall shadows... Although most of them came from rural side, they even forgot games they once played in villages. Rathe,r children of gecekondu do not play, they strive in dust and soil...

Gecekondus are a concentration (camp) of unemployment... Coffee houses are full of peoples during all day. They play gamble...I try to confirm this with camera. Owner of the coffee house prevented me... However, gamblers were not worried about this. But owner of the coffee house was afraid of closing down the shop. I try to speak with one of them: "I am companion of man about town" replied ironically. His friend next was suffering: "I looked for a job for days long, my feet get sick of walking. There remained no road I did not walk, no door I did not knock, no patron I did not plead. But no one gave me a job. Even one of them advised me 'to suicide'. Now we try to survive by plucking one another..." Working women are also few. They sit in wall shadows and make gossip... Crisis of unemployment causes big depressions whether material or moral. It destroys respect towards each other and towards the public authorities. Hatred and hostility replace it... Fear, despair and astonishment due to unemployment put gecekondu people in a situation of terror... Dream of a better life; became a distress and suffering in gecekondus. This may cause serious problems to state.

Gecekondus is a concentration of ignorance... Literacy is well down... Except of civil servants and drivers all are illiterate. I did not come accross any literate woman. Due to financial and adoptive unsufficiencies childrens who graduated from primary schools can not follow superior ones. And who follow were unsuccessfull...They do not have financial resources for school expenses nor space to work and educational tools in their homes. When this was coupled with rising cost of living? Then they are put in a job. One of a local association commented on this issue: "We need a secondary school. We can not send our childrens to remote places. We can not support additional travel and meal expenses and allowances... Even a school won't be enough. We need reading halls for childrens can work after school hours. We can not save a place of work in these narrow gecekondus.As you see seven people share a room..." There was an interest and willing for education in gecekondus. Yet, they do not have means, they are helpless..."

Then the interview concludes with the same tone of narrative as expected:

“Emptiness, intimidement and confusion eroded confidence and respect to public authorities. Already nervous and desperate gecekondu people conflict each other very frequently. Above all the vagabonds? They abuse peace and security of the neighbourhood. They disturb women, they beat people just for fun. Lack of a police station in Gülveren neighbourhood of eight thousand gecekondus looks like encouraging vagabonds and who tend to be criminals... Even worse, a primitive understanding of law and order based upon self defence of interests begun to make its own way in gecekondus... Robbery is very common in nights. Civil guards do not fullfil their duties. Head of the majority party's local office: "There is no policestation here. We are not in security. We have enough of vagabonds. They beat, they abuse womans, disturb neighbourhood when they are drunk...We 
can not sleep in peace! We only hear civil guards warning whistles once in a month in paydays (!)"

The demand of a payment for occupied lands by the Municipality of Ankara from gecekondu owners really surprised them. One of local officials: "The Municipality of Ankara decided to deport us from here... How we can find such an amount while we hardly find the food?" Another one was saying: "Patch over patch!... Another patch on our back... Municipality serves other areas of the city but asks the expenses from us..."

Soon last ray of lights of the sun will be dissappeared beyond hills...Poor loneliness of the night will cover gecekondus...In tired darkness, streets will be deserted... Adieu Gülveren..."

This quotation above, reflects many popular approaches and expressions of the period towards gecekondus. The general pessimistic atmosphere with continous accentuation of misery, deprived physical space, social inequality, lack of infrastructure, inadequate social services and equipment, unfavourable living conditions etc. are major themes and characteristics of the text from first hand wittness. As mentioned before, this type of perception full of pity is natural for its period which underlines the marginality of gecekondus and can be found in many similar narratives particularly through 1950s and 1960s until mid of 1970s. Therefore it is highly typical for its time.

In October 1970, a disease which caused 52 deaths in a month broke out in Sağmalcılar, a popular and poor gecekondu settlement in the outskirts of İstanbul. This naturally became a major subject which occupied press headlines along October and November 1970; causing intellectuals to reconsider living conditions of gecekondus. Among similar, a selfexpressive evidence of this paradoxical attitude of middle and upper class bourgeoisie and intellectuals was to be found in excerpts of a long article published in a leading centre-left newspaper in 1970, with the irritating title: "Damned of the Metropolis". It summarized almost a whole process and history of squatting and gecekondus in İstanbul and Turkey, with significant stress and values of a left wing urban intellectual:

"In most big cities there are second class citizens. They are generally immigrants for second class works and jobs: they produce what the real urban dwellers consume. The big city can not live without them. But when they outnumber what the city needs, they become a burden. The city is suddenly transformed into an enemy for them and tries to send them back. Gecekondus of İstanbul first appeared in the 16th century. According to official correspondence, gecekondus encircled the city through gardens and agricultural terrain. Around 1700s they penetrated into the city. Constructing on the city walls was forbidden, however this was never taken into consideration. The second rush of gecekondus in İstanbul was in 1950s. The reality of the gecekondu constitutes paradoxical, multi-aspected and complex phenomenon like factors which created it. On one side it is the appearence of an important stage in social change and development. It marks the beginning of industrialization and is the result of demand for labour at the outset. Inhabitants of gecekondus whom are mostly perceived by comfortable bourgeoisie to be compassionate are people who succeded a big leap forward in their private life and are in a better situation in almost every aspect with regard to their precedent living condition. Some experts even find in this reality a dynamism which will take the Turkish society towards a better future."

Gecekondu is also a product of big inequalities. Old inhabitants compare themselves not with their previous situation but with other city dwellers. 
21. “Keşanlı Ali Destanı (The Legend of Ali of Keşan)" (1964) is an outstanding and almost early example of reflection of arts and literature on the gecekondu phenomenon, interpreting the gecekondu reality in the form of a cabaret theater. Verbalized in one of the lyrics of the cabaret, the play is a narrative making of a local hero based upon real events and a real personality.

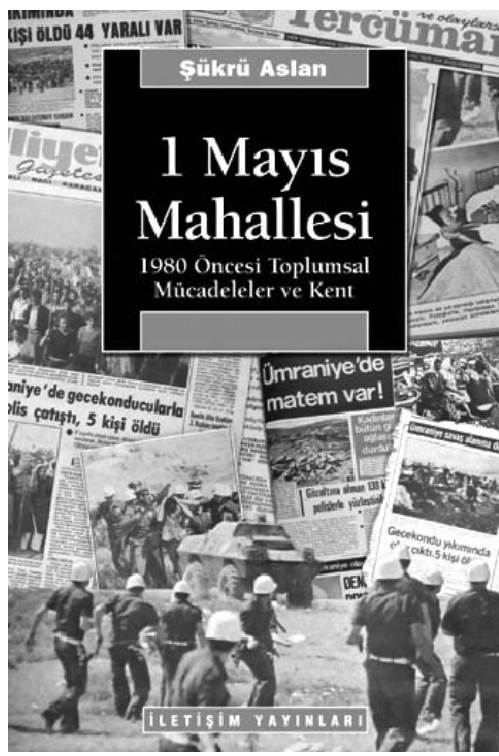

Figure 8. During the politicization period of 1970s, 1 Mayıs Mahallesi (The May Day Neighbourhood) in İstanbul, had reasonable popularity due to its role at the focus of politic struggles, but particularly for its role in "utopic", "new order" experiments. The book which reveals this interesting chapter of Turkish gecekondu history, may be considered one of the important 'first hand' gecekondu narratives.
They think otherwise about their poor environments, polluted waters they use and disdain of other city dwellers. If each family in İstanbul consumes meat once a week, there would be a shortage. If this doesn't happen, it is because some consumes abundantly while some others don't. These are gecekondu areas such as Sağmalcılar and Zeytinburnu.

The city of İstanbul has a palace of culture which cost 90 millions and 90\% of its population may never have access into it through its thresholds. Half of its population has not received yet any municipal services. Peoples of gecekondus are left into garbages and dirty sewage waters in an age of science and hygiene where regular daily baths and vitamins for small childrens are viewed as indispensability. Peoples of gecekondus can only have better living conditions as much as they fulfill needs of urban dwellers. Broke out of a disease such as cholerain Sağmalcilar should not be interpreted as a coincidence...

In his famous novel of "the Plague" on effects of a disease Albert Camus describes the situation as follows:

"Doctor Rieux is living permanent repetitions of the same scenes. Even the plague became an everyday routine. The only changing thing was the doctor himself... Sense of compassion is now nonsense. One has enough of compassion when it becomes useless... If a man wants to share sadness of others, there will never remain time for its own happiness. This was necessifiying to make a choice." The damneds of İstanbul hopelessly waited for the choice of comfortable urban dwellers." (İpekçi, 1970)

One of the original narratives of early gecekondus covering its many aspects in its rich humanism is the well-known masterpiece of Turkish cabaret theater "Keşanlı Ali Destanı" (The Legend of Ali of Keşan, 1964)(21) of reknown Turkish writer Haldun Taner (Figure 7, 8). The work, which represents a vivid and impressionistic description of gecekondus in an era of innocence and marginality within a social and physical context, and which was also adapted for cinema, is inspired by the story of a local good tough guy during the early 1950s at Ankara's famous gecekondu site of Altındağ. Thus, the gecekondu quickly becomes a perceptible and important symbol of social inequality and injustice. Parallel to this, the gecekondu gradually earns a wider interest and a place in works of popular culture such as popular music and cinematography throughout the 1960s.

The physical condition of gecekondus is also improved significantly between 1960 to 1970, and many scientific research and discussion on the phenomenon emerged. In one sense, gecekondu consolidated its permanence, improve their conditions and creatively find alternative ways to articulate with the system, mocking all initiatives to eliminate or to reform them. They become permanent, while improving in structure, and becoming more comfortable and more generous in size. Cheap briquet is still the material most widely seen, although even the use of brick is spreading faster. Gecekondu "lords" too, become a more organized "institution" of patronage. As a result, 'ready to use' gecekondus as a new way of supply and gecekondu construction during hours of daylight appear (Pulat, 1992, 142). It is by now possible to construct gecekondus in times that may span a couple of days with necessary materials, skills and organization, and under sufficient patronage and protection. 
22. May Day neighbourhood (later Mustafa Kemal) in İstanbul gives an outstanding, untypical and highly popular example of a politicized gecekondu neighbourhood of 1970s. First settlers arrive in 1958 to this area which was partly a quarry and waste disposal area. However even the pioneers had to pay for the land (Aslan, 2003, 96). In 1960s the land was declared Gecekondu Prevention Zone by the Ministry of Resettlement and Housing. During the second half of 1970s, radical left groups took over control of the area under the patronage of People's Committee and the site became a "liberated zone". Thereafter, a new experimental system out of mainstream, general rules is put into action within the neighbourhood. Planning of the site was among various practices realized by People's Committee. One of participants of this experiment comments: "In the beginning, it was clear that any planning was not feasible. Then after the participation of revolutionist groups, a plan and design are tried to implement..."(Aslan, 2003, 120). The planning of the site restarts in a more organized and equipped way following the incidents of largest clearance of gecekondu history of Turkey where 9 peoples died in September 2, 1977. "Yet this clearence at the same time provided a basis for the implementation of a more regular plan. Assistance is asked from İstanbul Branch of the Chamber of Architects on this issue. Committee, longtime worked on this plan in collaboration with representatives of the Chamber of Architects and with some NGOs" (Aslan, 2003, 120)

23. September 12,1980 is the date of the military intervention in Turkey where the Parliament was abolished, the Constitution and basic cnstitutional rights were

suspended until the general elections of 1983.

24. From the book by Şükrü Aslan, 1 Mayıs Mahallesi.

25. In following days incidents appears in some dailys as follows: Cumhuriyet, in headlines: "Clash in gecekondu clearence: 5 deads" (September 3, 1977); Milliyet, second news in cover page: "Police clashed with gecekondu dwellers, 5 people died" (September 3, 1977) and in first page: "99 people interrogated by police on incidents in Ümraniye" (September 4, 1977); Son Havadis, on cover page: "Anarchists fired to the police: 5 dead" and sub headline:

"Incidents in Ümraniye during gecekondu clearence" (September 3, 1977); Hergün, second heading on the first page: "Reds who pretend resisting gecekondu clearence provocated people and caused incidents. 5 dead, 9 policemen out of total 44 wounded in incidents where long range guns were used" (September 3, 1977); Haber, in headline: "Bloody clash in Ümraniye, 5 dead" and in sub title: "Maoists amongst the people opened fire with long range guns" (September 3, 1977); Tercüman, on the first page: "The extreme left backed incidents in Ümraniye" (September 5, 1977) and on the same page: “Ümraniye Örnek Mahallesi (A gecekondu neighbourhood in Ümraniye) declared a "Liberated Zone" (September 6, 1977).

\section{POLITICIZATION AND SPECULATION}

In the mid-1970s $45 \%$ of İstanbul's population lived in gecekondus and gecekondus had a share of $39.55 \%$ of housing stock in İstanbul. The figure was $65 \%$ for Ankara. The population of gecekondus within overall urban population has also risen gradually nationwide. In 1960 while some 13.5\% of the urban population was living in gecekondus, this reaches $23.3 \%$ in 1970 and $28 \%$ in 1974. It is estimated that almost one tenth of the total population is living in gecekondus at that time (Tuna, 1977, 3).

Furthermore, gecekondus became subject to land speculation in the 1970s for the first time, due to high inflation. Gecekondu land now became an important source of investment and speculation. In 1970s gecekondu families would experience small size land speculation (Şenyapıll, 1981, 48). And yet this was mostly valid for the early generation of gecekondus that were mostly situated around urban centres or in close vicinity to them. Following the foundation of metropolitan planing offices for İstanbul, Ankara and İzmir, in the 1960s a new more analytic and relatively more creative planning practice came into operation. In this context, one of the major dynamics of İstanbul's urban planning and development agenda beyond 1970 was determined as 'decentralisation'. We should note that decentralisation trends in İstanbul following the 1970s mostly influenced early gecekondu areas built in the 1940s and 1950s.

This is however, a strategical turning point from which gecekondus begin to move into another level of legitimacy. The first multi-storey buildings in early gecekondu areas built by owners and developers also appear during the 1970s, as a perceptible result of this new era. Increasing use of concrete as building material in gecekondus is another significant aspect of the 1970s. Organisation of gecekondus even goes further in 1970s in order to create an illegal market of ready to use plots and houses. The market is under control, or patronage of local "entrepreneurs", or groups of influence in some areas and political groups in some other places. As a result of increasing political power of gecekondu areas, significant improvements took place in terms of infrastructure, public services, urban planning and spatial quality, particularly in the earlier gecekondu areas.

One main characteristic of 1970s in Turkey is political polarization, where political camps and ranks became sharper. Gecekondu population, who had been generally in favour of conservative political programs and who previously backed right wing political parties during the 1950s and 1960s with the hope of integration into the system, in 1970s turned into another direction and began to vote for to alternative programs of left wing opposition parties, which promised reform of the system itself. One of the major characteristics of 1970s is economic crisis coupled with political turmoils which particularly domine the society during second half of 1970s. In other words, this is the period where urban population was highly divided politically into different groups, ideologies, or opinions, and in a situation of conflict against each other as well as against public authority (Aslan, 2003, 69). This general social turmoil emerged from economic crisis and political unstability, found the way of self expression in gecekondu neighbourhoods easier than in any other urban area. All through this period, gecekondus sometimes appeared as 'liberated safe zones', which were shared and considered to be free under 'patronage' of concurrent political groups, as a dominant and widespread phenomenon of 1970s urban panorama. Sometimes they became the scene of small size utopia experiments of 'idealized' society models of a corresponding politic group. 
26. Hürriyet, headline: "Something happening in İstanbul" and in sub-title: "Governorate gets what they ask, after a 48hour "search operation inside the May Day Neighbourhood" (March 20, 1978); Tercüman, in headline: "Police for the first time penetrated the Liberated Zone since months" and in sub-titles: "A "People's Court" where 5 right-wing workers are judged is found. Some general stores are entitled as "Comrade" (March 20, 1978).
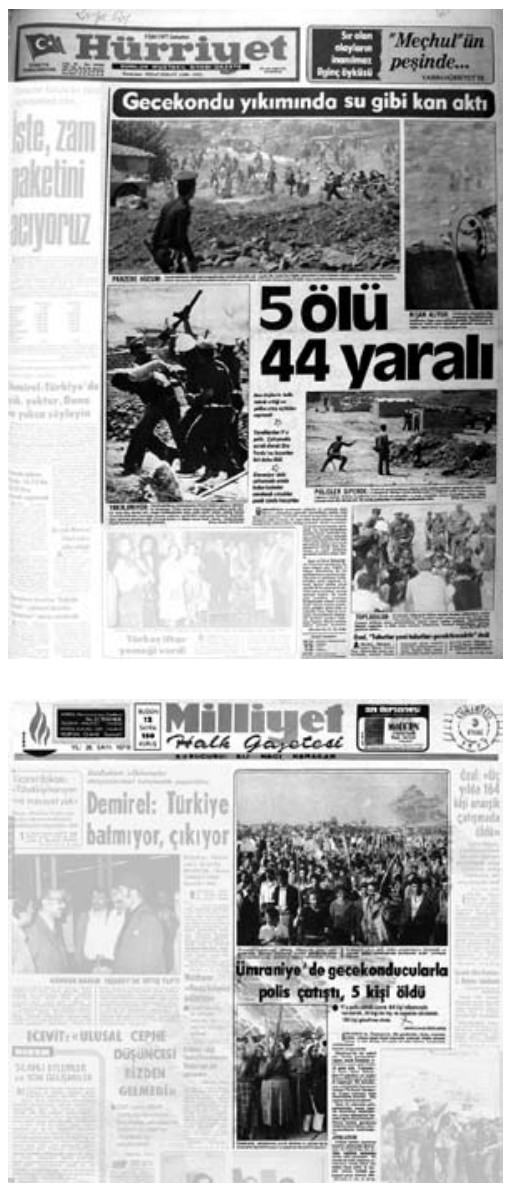

Figure 9, 10. "5 Dead, 44 wounded, blood was shed like rain in gecekondu demolitions" (Hürriyet, 3 September 1977) and "Police clash with gecekondu dwellers, in Ümraniye, 5 people dead" (Milliyet, 3 September 1977). Large scale demolitions of September 2, 1977 in May Day Mahalle and following incidents mostly echoed in mainstream press as ordinary police operations for law and order, neglecting demand for shelter and social aspects.
Like gecekondu settlements which symbolized the period of innocence and marginality, such as Zeytinburnu in İstanbul or Altındağ in Ankara, period of politic struggle also created its stars. For example, gecekondu settlements of Ümraniye and Gültepe in İstanbul gained a reasonable popularity among similar others due to their roles at the focus of politic struggle, but particularly to their place in 'utopic' 'new order' experiments. This is particularly valid for the 1 Mayıs Mahallesi (Mahalle of May Day, later the Mustafa Kemal Mahallesi (22), of Ümraniye District at the outskirts of İstanbul, thi inhabitants of which held an unchallengeable leading role in a 'new order' experiment as well as a justified position within politic struggles of pre-1980 era. As mentioned in a research about this curious experiment: (Figure 9)
"The neigbourhood that flourished in 1960s through a typical gecekondu system, later went into a politicization process which was also repeated in many gecekondu areas of this period due to problems of land distribution and conflicting interests. In order to solve these kinds of problems, some local initiatives emerge, mostly known as "People's Committees" and the neighbourhood begun to call itself "May Day Mahalle (Neighbourhood). At the same time, the neighbourhood becomes one of the major fields of politic conflicts through politic polarization of 1970s. In common memory, it also emerges as one of leading images of "pre September 12, 1980 period" (23). For those who think that this was a time of terror and chaos where public authority was in a situation of almost weakness and disability, it was the symbol of all kinds of negativity. And for those who perceive signs of a revolution in politic and social mobility and dynamism of 1960-1980 period, it was one of the symbols of hope" (24).

For bourgeoisie who largely inhabited in planned areas of metropolitan areas, an early perception of gecekondus as a threat appears to be created through politic and social turmoils of 1970s. However, evident reasons would not be problems of adaptation of gecekondu population to urban values, nor their politic choices alone. Maybe more than this was the emergence of a new 'utopian' model apart of legitimate social, economic, legal-administrative rules and institutions in gecekondu areas "liberated" by radical left wing groups. As happened in the May Day Mahalle in İstanbul, it looked obvious that attempts for new social models in some gecekondu areas through the patronage of local iniciatives such as People's Committees should mostly be perceived as a general threat to status quo by middle and upper class urban dwellers. For example, large scale demolitions of September 2, 1977 in May Day Mahalle and other incidents that followed mostly echoed in dailys as ordinary police operations for law and order, neglecting political aspects. Mainstream press generally preferred to reflect incidents as ordinary police affairs with a limited touch to its importance, while radical right wing press preferred to dramatise events, as terror by the gecekondu people to oppose and clash with security forces by gun exchange in collaboration of illegal left wing groups, in order to obstruct a legal procedure $(\mathbf{2 5})$ (Figure 10, 11). It seems that, these incidents only served to consolidate the image of the May Day Mahalle and some other similar gecekondu neighbourhoods in public opinion, as illegal areas without law and order and where public authority could not penetrate. That's why, uninterrupted presence of security forces in the May Day Mahalle following the incidents and provision of some public services and equipments such as a school easily found a place in newspapers, in the way of success of state authority against a threat for public order (26). A relationship of predecessor and successor might be valid between the images of revolting gecekondus totaly in disaccord with the status quo of 


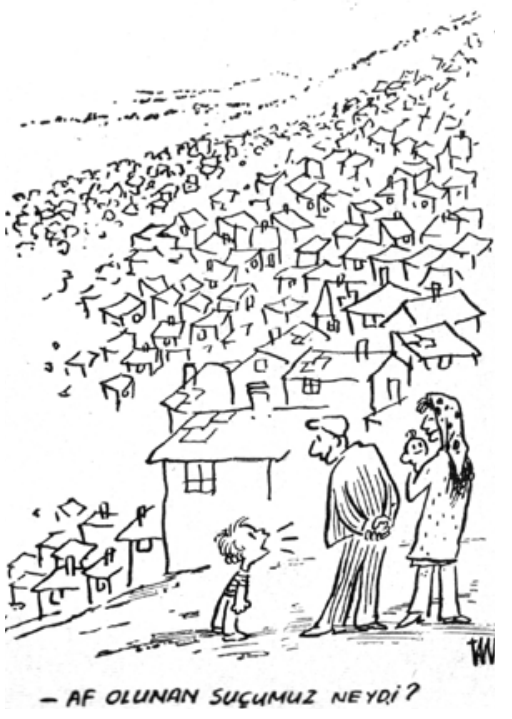

Figure 11. 'What was our crime they declared amnesty for?'

A cartoonist interpretation for the Draft Proposal for the Urban Amnesty Act. All through the history of gecekondu, position of the press was generally in favour of gecekondus (Tan Oral, Cumhuriyet, April 1983).
Figure 12. 'Let's erect the statue of Sinan'. The "Great Architect Sinan" of Ottoman Classicism of 16th century has been always a primary figure of national pride; however, construction activities in his homeland have been largely dominated by gecekondu buildings in the 20th century. This paradox has been emphasized quite frequently, where this one is about the Urban Amnesty Act of 1984. (Mim Uykusuz, 1984) 1970s and "angry outskirts" of 1990s. Moreover, all are nourished from the same source of social unrest.

Attitudes of technocrats whether in government or in local administrations also changed significantly during the 1970s, in a way to accept the realities instead of conflicting with them, to make improvements through development. One should keep in mind that this was a period in which left-wing political programs and views reached a considerable degree of influence and dominance whether in government, in local authorities aor in public opinion. One of tha major aims of this approach was to generate a policy to transfer resources to gecekondus in order to solve problems associated with income inequality. The Third Five Year Development Plan approved in 1974 considered another aspect of the problem as follows:

\begin{abstract}
"Considering general charasteristics of the gecekondu, the Ministry of Resettlement and Reconstruction will begin to establish delivery channels and technical support offices to deliver necessary construction materials sufficiently and on time for a predesigned nucleus house plan to those in need at gecekondu areas. The Ministry will foster the possibilities of using prefabricated houses in social housing" (Tuna, 1977, 4).
\end{abstract}

The production of nucleus housing like gecekondus, through use of prefabricated technology and their supply for rent was launched by the Government in the mid-1970s as a new policy and method in improvement and elimination of gecekondus. Even, a national project competition under the title of "National Project Competition of Architecture for Rent Houses in Gecekondu Prevention Zones and in Underdeveloped Areas" is organised a few years later in 1981 by the Ministry of Resettlement and Reconstruction (Figure 12). Here, Ministry tried to implement aims of Development Plan via results of a competition. Participants were asked to develop typical house projects for a household of 4-6 inhabitants and convenient to four different climate zones in Turkey. However, the competition did not represent more than another example of the wellknown inadequate conventional reading of the gecekondu reality solely in terms of a shelter problem.

Academic perception of the gecekondu underwent a process of specialisation and maturation during the 1970s, compared with previous decades. The political activity of the decade also reflects itself in urban research. The rise in number and variety of institutions interested in urban problems is one of significant characteristics of the period. In addition to universities, ministries and government agencies such as SPO or metropolitan planning offices, municipalities, the union of local authorities, professional unions, cooperatives and even newspapers took part and / or support several popular, academic and scientific meetings, surveys,

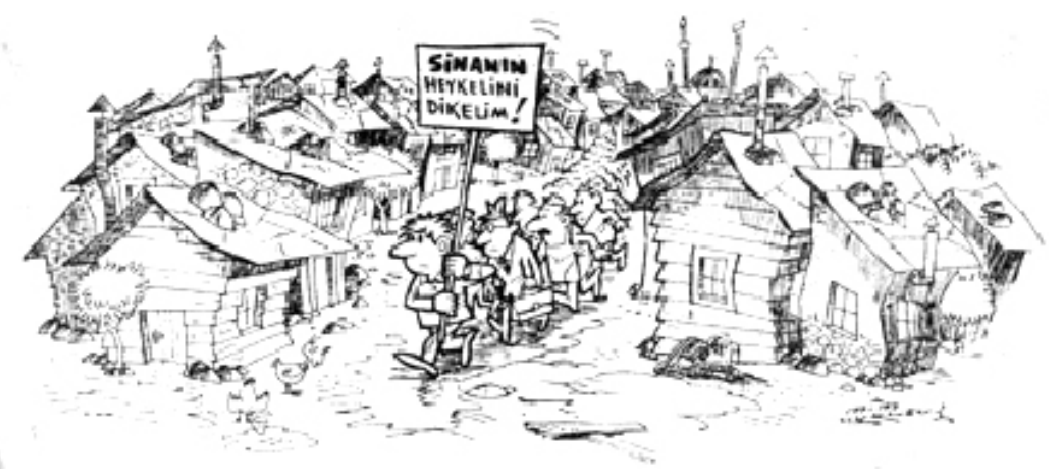


researches, studies, publications about urban problems in general and the gecekondu in particular with special attention to public rights and interest during this active and fertile period. As it was pointed out in an article, a specialisation parallel to the considerable quantitative increase in urban studies and debates also marks the character of this period. Therefore, studies on the gecekondu generally become a sub-area of specialisation of housing studies. As it is pointed out urban studies underwent a process of diversification in the early 1970s, then an infiltration in terms of practice during second half of the decade, and academic profoundness in the early 1980s (Bademli, 1984, 301).

However, it seems that the conventional approach to tackle with the gecekondu problem within urban order and housing problem still had a considerable weight in 1970s. The following words are from a conference organized by İstanbul University in 1970s:

\begin{abstract}
“...Existence of a shelter problem in Turkey and in almost all developing countries in extreme poverty is a reality beyond any debate. Thus, gecekondus that surround large metropolitan areas are attracting attention in numbers without requiring statistical analysis and large districts built by gecekondus around the roads to airports or city entrances are so apparent as to make any careful observation obsolete. This is obviously an uneasy and uncomfortable situation for public opinion and governments, as well as for the residents of such areas themselves. Therefore, government financed 'gecekondu prevention zones' were put into operation in order to find a solution to the gecekondu problem and it was supposed that the, spread of gecekondus would stop while assisting those in misery and improving the remainder" (Tuna, 1977, 1).
\end{abstract}

Three facts about gecekondus are obviously emphasized in the passage: the gecekondu is a problem of housing, misery and poor living conditions. The current situation of spread of gecekondus should be stopped, and a part of existing stock should be improved while the rest should be eliminated. "Unfortunate people whose villages no longer accommodate or shelter them" are also mentioned within the speech together with the following critique of planning and urbanisation politicies:

"...in our city, the situation where a modern "urban and housing policy" never came into practice and was even never really understood, provided the basis for "law of the jungle" in the land and property market, in rental charges and in prices of construction materials, even enforcing and provocating the actual spread of gecekondus" (Tuna, 1977, 3).

A considerable increase in works aimed at evaluating urban planning experiences also occurs in these years together with that of cities, urbanisation and urban problems (Bademli, 1984, 302). However, empirical studies and field surveys still hold absolute dominance as in previous decades. A bibliography dated 1980 cites a total of 87 scientific-academic publications by local or foreign experts on diverse aspects of the gecekondu in Turkey realized upon that time (Şenyapıll, 1980). Adoption of planned development in Turkey beyond 1960 and supportive attitudes towards scientific studies by certain government agencies, established within this context such as the State Planning Organization (SPO) or the Ministry of Resettlement and Reconstruction had undoubtely a positive influence on this. 
27. "Varosh": a name of Hungarian origine, derivative of the name "var" (castle, city walls etc.) which means settlements beyond and around city walls and also marks the outskirts of a city. In Turkish: "varoş".

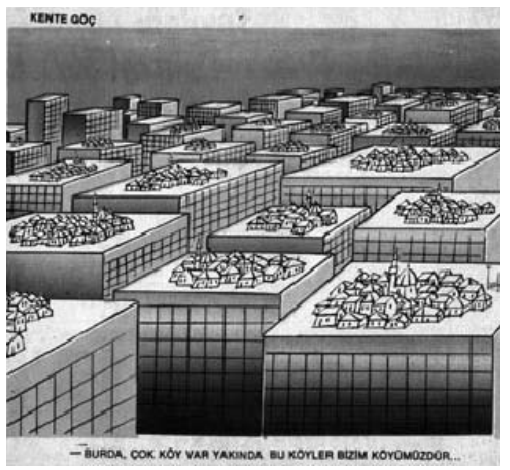

Figure 13. 'Migration to the City: There are many villages here nearby. These villages are ours'. A cartoonist adaptation of a famous Turkish school song to underline the new panorama of gecekondus in 1980s. Contrast and contradiction between gecekondus and planned "modern" urban texture of cities became more visible, after adoption of neoliberal economics in Turkey from 1980 on. (Turhan Selçuk, Milliyet, 1982)

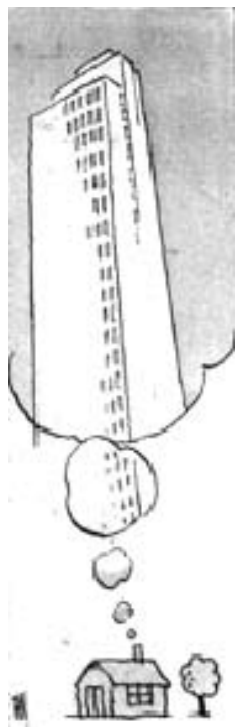

Figure 14. At the outset, gecekondu was an alternative to legal and institutional housing production and city building. However, they tended to become permanent, they became a tool of reproducing mainstream housing and city building. (Tan Oral, Cumhuriyet, 1984)

\section{ILLEGAL URBANISATION: 'RISE OF THE OUTSKIRTS (VAROSHA)'}

The 1980s mark another important turning point for gecekondus in Turkey (27). From the 1980s onward, speculative qualities and the motives behind the gecekondu gradually become more dominant over the mere shelter aspect. This was a time when the gecekondu lost most of its initial innocence as well as its moral legitimacy and became an ordinary illegal construction activity. And since the gecekondu was transformed into an illegal building, a dramatic rise in construction costs also occurred due to the necessity to build in a more lasting way demanding now a higher level of skill. Multi storey, unplastered concrete buildings became major elements of physical appearence in illegaly built up areas. One of natural outcomes of this is a decrease in property ownership in favour of rental houses. The ownership pattern is one of the distinctive aspects of gecekondus in Turkey. Gecekondus were mostly built initially upon land belonging to state, thereafter spreading to land of shared property. This spread of illegal buildings over shared property lands becomes particularly significant after 1980. Indeed, according to 1988 figures $60 \%$ of 2.6 million lots within the municipal boundry of Greater İstanbul are of shared property status. This actually indicates another phenomenon, namely the spread of shared property. Buildings over a shared property land, formed clusters which had an organisation in itself. Albeit, this spatial organization was generally incompatible with comprehensive, large scale planning methods. While local authorities became increasingly inefficient to control the spread of illegal buildings, patronage relations in gecekondu areas became more and more organized in the hands of what may be called the gecekondu mafia.

A change in legitimacy and raison d'etre of gecekondus inevitably brings another change in related literature. "Gecekondu" is no longer a sufficient title to encompass all aspects of the phenomenon related to urban, legal, social, economic and cultural characteristics. Instead, new and different terminologies come into use to cover different aspects of illegality. The terminology of 'illegal construction' then increasingly replaces 'gecekondu' especially in academic literature, and it also cover particularly the legal and urban aspects of the phenomenon from the 1980s onwards. The urban amnesty of 1984 and new building rights for gecekondu areas which became operative following urban-improvement plans should undoubtly be considered as a primary factor in the process of transformation of gecekondus to illegal buildings. However, it is not possible to claim that this process that stretches from the urban amnesty of 1984 to urban improvement plans is not perceived with a critical eye by the entire expert community. For example, the below quotation that represents a positive view is from an issue of official Bulletin of the Chamber of Civil Engineers, dated to the days when the law was seriously criticized and under attack by many experts and professionals: (Figure 13, 14)

\footnotetext{
"The Government is engaged in a major effort to secure the lives and property of people who live in such areas, and in the envisaged improvement of hygienic conditions and structural consolidation of those houses through the "Act of Urban Amnesty", which covers the "gecekondu". In order to ensure efficient execution of the act, engineers and architects are asked to make gecekondus into liveable places through the establishment of "private technical bureaux" (İnşaat Mühendisleri OdasiChamber of Civil Engineers, 1984, 2).
}

It seems that the opportunity to acquire a land/property in metropolitan areas which was undirectly legitimized by the state for inhabitants of 


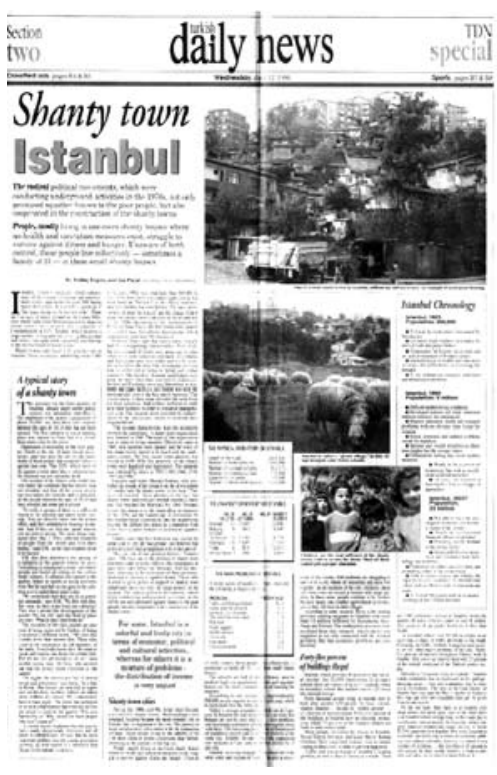

Figure 15. The United Nations Habitat II Conference in İstanbul in 1996, gave an impetus for a fresh start to discuss urban problems of Turkey and İstanbul. Before and after the conference, many news, reports and articles appeared in press to reassess dimensions of the problem and to stress the acuteness of the situation. (June 1996).

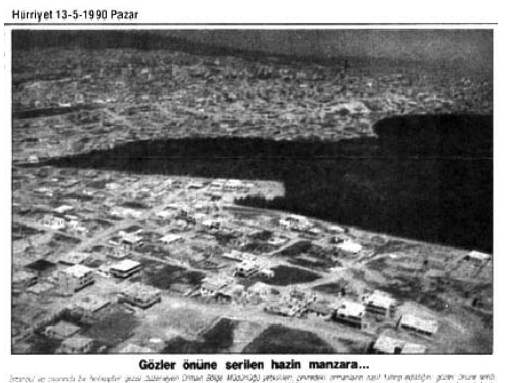

Figure 16. "Forests of İstanbul also vanished". Dimension of illegal urbanisation after 1980 outnumbered and obscured the "legal" city, spreading over forests around İstanbul. The "era of illegal cities", warning about "mass death and destruction" was in the air. Threats about the natural resources of air and water was the leading issues to scrutinize perception of illegal buildings in public opinion in 1990s. However, this time the object of anger was not gecekondus at all. (Hürriyet, May 1990) gecekondus, who were amongst the poorest of society, became insufficient from this date on. Newcomers were now dependent on the city and they were a lot better off $\mathrm{n}$ comparison with their previous rural living conditions, and they even accumulated some savings. Yet it is wrong and misguiding to consider this betterment as an advance in social class and status as, sometimes interpreted (Akbulut, 1996, 357). Even newcomers were not yet totally urbanized, although they were no longer rural people and the "one room gecekondu" could no longer satisfy them. Furthermore, rapid urbanisation, high inflation and a growing economy were pumping demand for urban land and properties in large metropolitan areas. While illegal buildings spreaded over metropolitan areas, this trend became almost a general practice particularly after 1980. The following decade would witness gecekondu areas being transformed irreversibly, resulting in rush of constructing multi storey illegal buildings, which was out of control especially in İstanbul.

One of the critical questions at this point should be about the nature of continuity between the gecekondu and that of illegal building. Is it possible to consider illegal building as an evolved version of gecekondus? There is a strong qualitative difference between the two, that is not solely limited to physical qualities nor external appearence or size. This is in fact related to processes that allow and legitimize the two phenomena. As an approximation, contrary to the gecekondu prior to the 1980s, which seeks to attain a limited individual benefit, and which possesses significant characteristics of social justice and provision of cheap labour, it is possible to characterize the motive of illegal buildings as pursuit of a goal of substantial economical benefit. But another major difference is the way and the aim they built for. In response to the temporary nature of the gecekondu, which tends to articulate and unite with the system, illegal building represents a permanent and even a 'post-modern city', alternative to modernist urban structures and values.

It is possible to compare the relationship between the gecekondu and the illegal building to that between a market and subsistence economy. Like the profit motive of the market economy, in response to the limited utilitarianism of a subsistence economy, the speculation motive is the major incentive giving birth and meaning to illegal building, in contrast to the limited individual benefit mentality of the gecekondu. Illegal buildings replace planned urbanization, which is expected to be the successor to gecekondus. In other words, the gecekondu turns into illegal building with confusion, defeating all expectations and predictions of transformation into planned urbanisation (Figure 15, 16). Furthermore, by thoroughly neutralizing modernist ideals represented via the 'planned city', once viewed as an example to follow for, the gecekondu makes meaningless some previous considerations such as 'temporary' or 'marginal', and even provides its own spatial production model to gain general validity. However, this should not be considered as a positive transformation due to qualities and orientation of dynamics it possesses.

Here urban property regulation plans become the fundamental urban policy tool of political authority as well as one of major indicators of its pragmatic approach to the gecekondu phenomenon during the economic liberalisation of the 1980s. The illegal land market has now more influence on urban development than its legal counterpart. Political authority is now considering and treating gecekondu phenomenon not solely a problem of urban shelter, urban development or a modernization, but a question 
Figure 17. İstanbul under 'occupation'; “Out of 227 million, 100 million meter square state land occupied by gecekondus in İstanbul." Land speculation and harm caused by gecekondus in big cities, particularly in İstanbul, was among the favourite discourse of press during 1990s. (Dünya, November 1996)

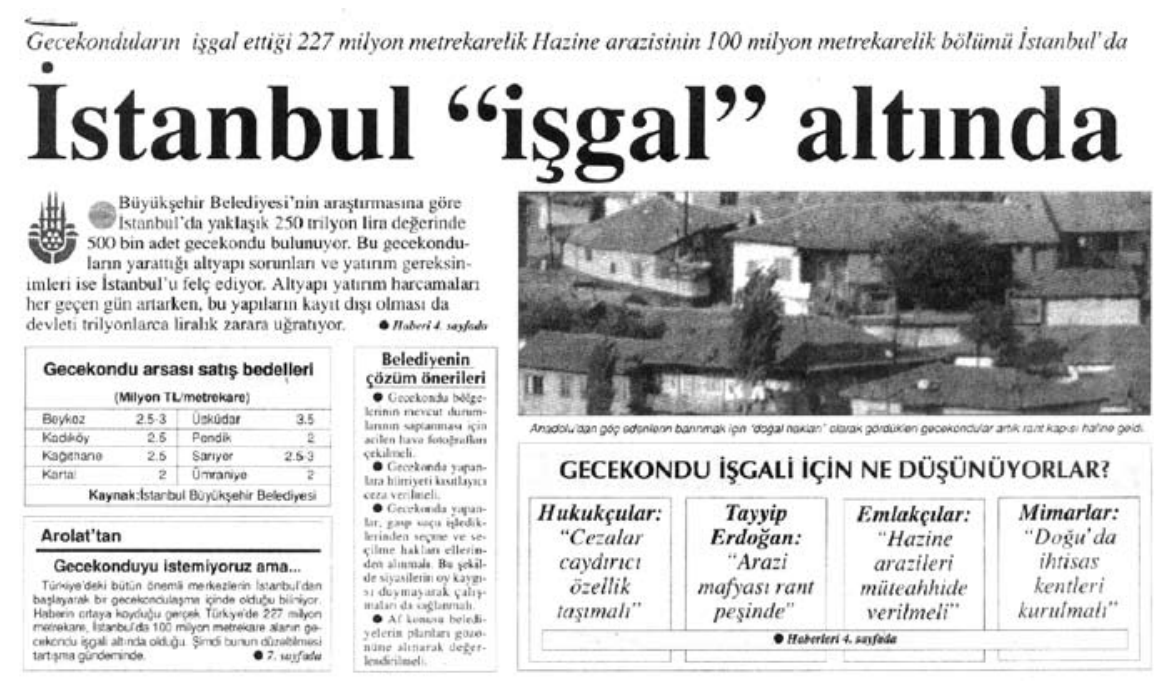

of property. This new pragmatic approach perceives gecekondu areas within the context of urban transformation and renewal opportunities they represent. Yet a change of property ownership is a prerequisite for this and problems related to property patterns should naturally be solved firstly. Urban property regulation plans are developed at this point as a tool to intervene in the existing property pattern in gecekondu areas and accelerate the process of ownership change (İnankul; 1990: 77). This was however, a belated leap. As a tool to legalize an illegality, urban property regulation plans satisfy some expectations with some degrees. They provocates land prices, rise excesssively in some places with new construction rights (İnankul, 1990, 83).

However, it is wrong to perceive the 1980s and 1990s as a uniform period in its entirety. In many ways of course, the 1990s represent a continuity and maturation of the 1980s. Yet at the same time 1990s is also a turning point that considerably differs from the 1980s. The 1990s is a period in which economic liberalisation is largely completed as mentioned above. However, this process turns particularly large cities such as İstanbul into consumption centres and social inequalities into income gaps. This is a gap which has a multitude of harmful effects on the social structure and which seems impossible to be covered through conventional means. On the other hand, adoption of the 'right of housing' among fundamental human rights during the United Nations Conference of Habitat II İstanbul in 1996 and its effect on human settlements and urban and housing policies had undoubtly a considerable effect on the general climate of urban studies of the 1990s (Figure 17).

If it would to summarize the overall gecekondu panorama of the 1990s in a word, "varosh" (varoş-outskirts) would be it. Academic studies still keep in these years to follow general conventional approaches to gecekondu phenomenon as a sheltering and housing problem of poors within a basic causal relationship of population increase, rural exodus, rapid urbanisation. However, fresh approaches and debates are flourishing. "Varosh", "immigration", "urban poverty", "illegal urbanisation", "illegality" and "violence" appear as new areas of discourse and themes of research, as well as the framework of debates of this new era (28). The illegal urbanisation phenomenon, which increasingly began to replace gecekondus, reflects into popular culture around a discourse of "illegalisation" and "varosh" 


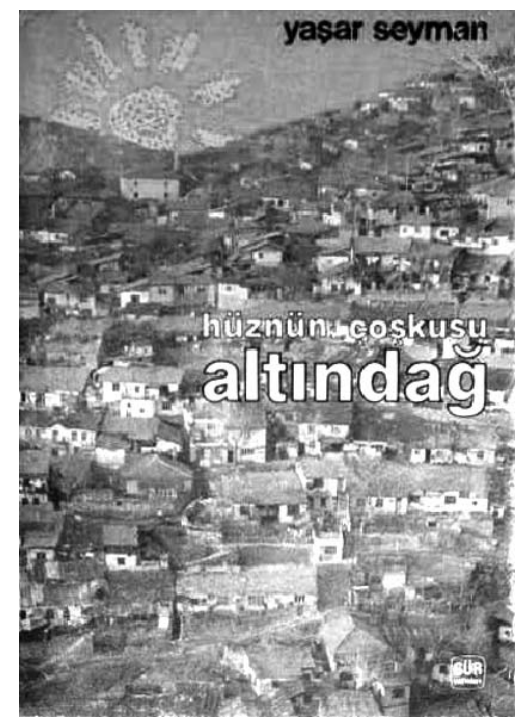

Figure 18. Another important narrative on gecekondus: "Enthusiasm of Blues, Altındağ", was one of the very few examples of gecekondu narratives from "inside". particularly during the 1990s. "Varosh" is largely used in 1990s by written and visual media. However, it is also welcomed to some extent in academic and professional circles also. Discourses of illegal urbanisation among scholars and that of the varosh in popular media are also accompanied by cultural fissures and identity problems as new topics of discourses during the 1990s. It is no doubt the media who made popular and fashionable the terminology of "varosh", however, its use went far back. In a quite earlier academic text of 1977 "varosh" appears as follows; “...our citizens from villages and towns who mostly immigrated to the varosh of big cities with large families by abandoning their livelihood..." (Tuna, 1977, 4).

The dimension of illegal urbanisation after 1980 which outnumbers and obscures the "legal" city, and threatens "urban" and "modernist" values, is largely echoed in debates of the period. Scholars and experts particularly relinquish their indulgent and dignified stance in order to emphasize how acute and desperate the situation has become, as expressed in following sentence, "If $65 \%$ of buildings in İstanbul are illegal, this illegality means there is a law beyond society, because this situation does not conform with laws" (Kuban, 1994, 80). However, as mentioned below, similar expressions were going to be repeated more frequently and they had almost become desperate beggings. While the gecekondu transformed into illegal urbanisation, land speculation also became the subject of a measureless plunder and even an "ideology" as some experts suggested (Uysal, 1994, 72). A suburban area and district located at outskirts of metropolitan İstanbul, Sultanbeyli is the most concrete and crystallized example of this 'ideology of plunder' and frequently appeared in urban agenda of İstanbul during 1990s. Even through expressions of its local responsables Sultanbeyli is a place where "disorder is the order" (Özgen, 1999, 15). With Sultanbeyli, an "era of illegal cities" starts up within the framework of unlimited urban freedom (!) where, every kind of building can be constructed anywhere with almost no limitation and rule (Uysal, 1994, 72). Echoing many others, a commentary of the period cited below provides a dramatic illustration of all fundamental concerns over the current situation:

“...city was turning into a concrete jungle, historical and cultural heritages were disappearing, İstanbul was fading away; worries were turning into warnings of "mass death and destruction" due to serious threats towards basic resources of life such as air and water" (Uysal, 1994, 72) [and continues in an even more dramatic and desperate tone], "even if we still can not see, hear or be aware that the sword of the Angel of Death standing above us, it is impossible to keep the gateways of the "Hell" closed any longer. Unfortunately, the innocent will also perish with the guilty in this Hell. The Hell does not distinguish between those setting fire and those trying to extinguish it."(Uysal, 1994, 74)(Figure 18)

The involvement of society almost as a whole is the proof that illegal urbanisation supported by illegality virtually turns into a sector during the 1990s. This is mostly due to the perception of the phenomenon as an organized, formal sector which is not a temporary disturbance, but now a permanent threat. In a decsription, this transformation process from "gecekondu" to "varosh" is expressed through the point of view of urban bourgeoisie as follows: "Innocent rural man is turned over time into a parasitical urban dweller" (Gürel, 1997, 25). But this kind of critic did not remain unanswered: "There is an illusory discourse particularly rising in recent years: An understanding which equalizes the gecekondu with land speculation and considers it as an occupant, corruptive and crude is gaining popularity among intellectuals and high income groups 

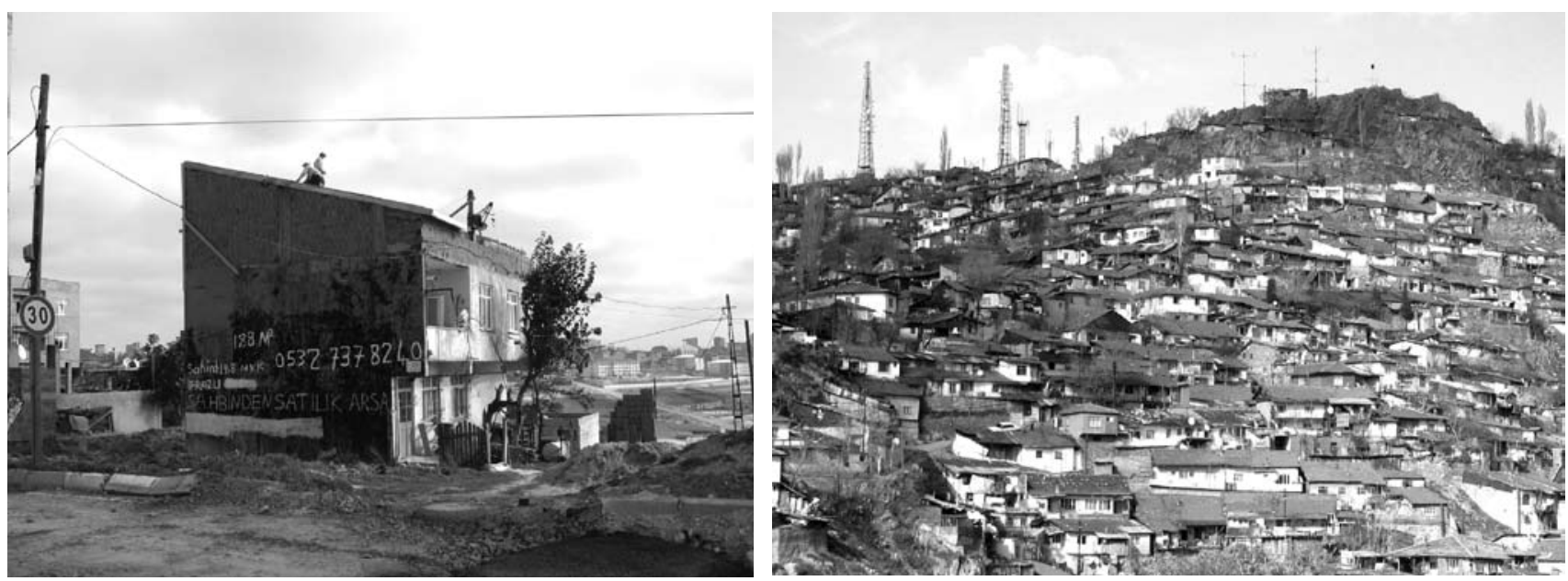
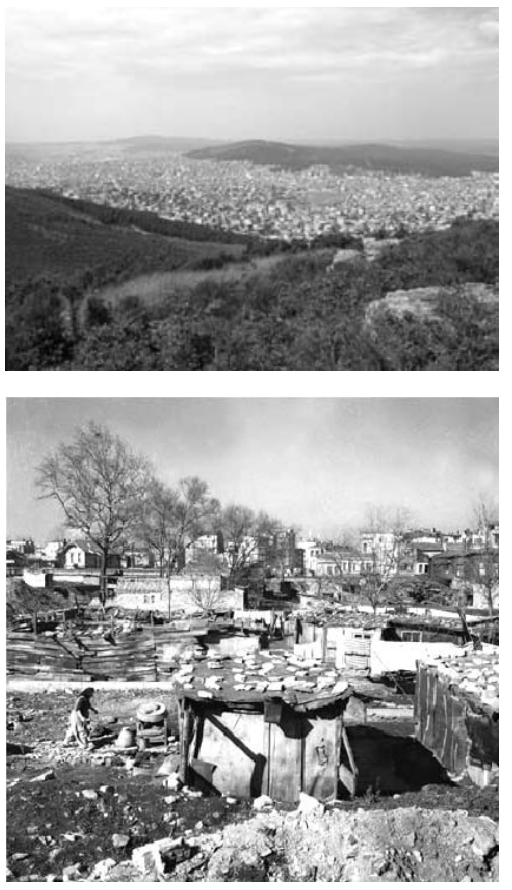

Figure 19, 20, 21, 22. Gecekondus in parade! A picture of gecekondu classic in its innocence, a gecekondu on the way to become a multi-storey, Arnavutköy (varosh!) district, İstanbul (2008); Altındağ gecekondus, Ankara (2010); panoramic view of Sultanbeyli (varosh!) district, İstanbul (2004); Zeytinburnu gecekondus, İstanbul, in 1950s. Through the history of gecekondus, almost every stage has its own areas which best represents the image of the gecekondu of the period. Renowned gecekondu areas of 1950s and 1960s such as Zeytinburnu and Altında $\breve{g}$, are replaced by Sultanbeyli or Gaziosmanpaşa districts of the varosh in İstanbul from 1980s onwards, as new favourite areas of gecekondu studies, migration and urban poverty. (Photos: M. Rifat Akbulut and Municipality of Zeytinburnu) of İstanbul" (Özgen, 1999) (Figure 19). Contrast arguments contribute to debates around the subject in many ways. A report of the Chamber of Commerce of İstanbul (CCI), from 1991 emphasizes the mostly neglected financial aspect of the phenomenon. According to the report, the total value of occupied land reaches 100 trillion TL if this land was legally developed and planned. This is a financial source offered to occupants (İTO, 1994, 78). The CCI report, also includes some policy measures within proposals for solution. Establishment of an "urbanisation police" who is recognized with necessary legal enforcement measures to prevent gecekondu and all sorts of illegal construction as well as elimination of existing ones (İTO, 1994, 79) should be interpreted such as reflections of highly eroded typical formal measures, which are too pronounced in public opinion by politicians and public authorities, and which are far from coping with actual conditions.

Following some qualitative changes in urbanisation urban studies and literature also underwent a transformation in Turkey beyond 1980. Empirical studies and surveys enter a period of relative stagnation, mostly replaced by theoretical works, particularly in academic literature. This is a process which may be defined as thinking about the city rather than to understand and analyze it. Therefore, while observations, impressions and personal witnessings replace data, research, survey and studies on one hand (29), an "impressionist" approach which may be defined as "reading of the city" becomes dominant over conventional methodologies such as explaining causal relations and structural analyzes. In any case, discourse is on the way to dominate emphirical studies, field surveys and data. The following expressions from the foreword of an oral history survey in the Ümraniye gecekondu area of İstanbul, provide clues of reasons of prefering impressionist methods for such oral history surveys; "the possiblity for researchers to empathise and witness the everyday lives of peoples who have different life experiences and social backgrounds is one of the aims of oral history research..." (İlyasoğlu, 1997, 92). In another similar survey, the method is defined as "face to face interviews with observation of a complete daily routine and self-narration of it by subjects" (Özgen, 1999). However, researches using a mixture of impressionistic and empirical methods are also published (30). One important and interesting novelty in gecekondu literature beyond 1980 is the rise of a self-narrative which has direct roots from the gecekondu itself as seen in the passage below, from a book based on a personal witness account of the famous gecekondu area of Altındağ in Ankara (Figure 20); 
29. Oral history appears to be a favourite method in studies about immigration and urbanization particularly in the $1990 \mathrm{~s}$

30. Sema Erder's book entitled İstanbul'a Bir Kent Kondu: Ümraniye (A Town Landed in İstanbul: Ümraniye) is a significant work of the period not only from the point of methodology but also due to its success to gather popular interest on a matter of the expertise. It should also be considered as a proof of how the "varosh" became an issue of popular interest during the period.
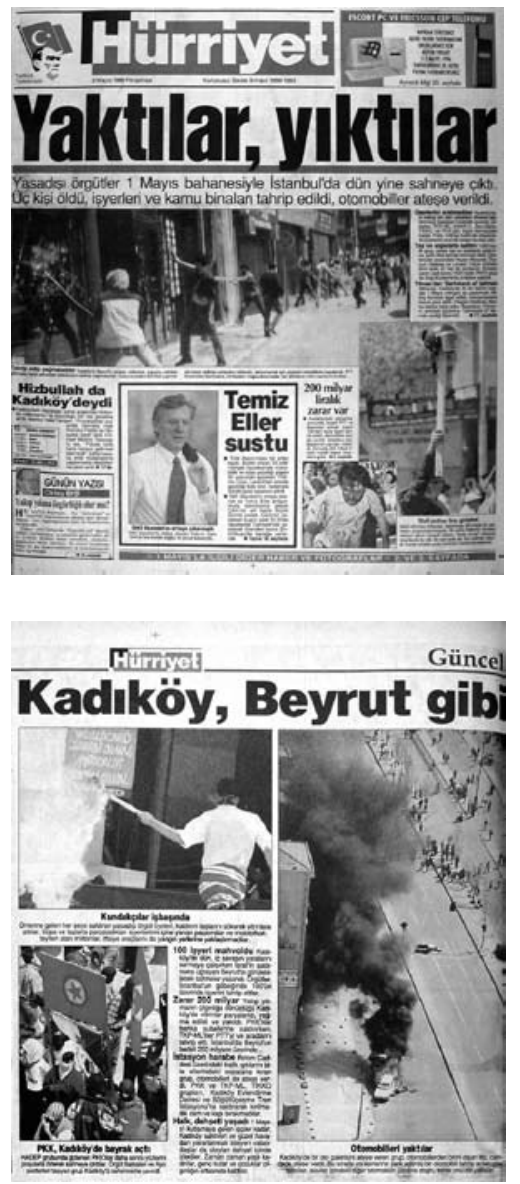

Figure 23, 24. "They set fire, they destroyed", "Kadıköy like Beirut." Incidents on the May Day of 1996 strengthen the associated image of "people from outskirts who love violence" in perception of tha public, particularly when tha centre of Kadıköy District in İstanbul was seriously damaged. (Hürriyet, 2 May 1996)
"I understand the heart of gecekondu through this new type of human. I understand women who fall far in love, children imitating villains of many vices, gamblers who surrender to the bottle, young men, and my people who share joy and pain with passion, who replace their missing garden in little flowerpots, after all, who add new child to their existing ones in their one or two room homes with the joy of life." (Seyman, 1986, 147).

This clearly marks a new type of literature on the gecekondu. It is neither a field survey, nor social or anthropological research but, a completely new type of narrative, straightforward and modest, naive and firsthand with obvious touches of popularism and it provides a rich collection of local human profiles in a way to be described as popular urban narrative or oral history.

Parallel to the changes in methods, discourse and points of view, popular gecekondu areas also differentiate from previous ones. Once renowned gecekondu areas such as Zeytinburnu and Ümraniye now became 'urban' neighbourhoods, as old gecekondus got integrated with the city and were transformed into formally-planned areas. And while favourite areas of gecekondu studies and gecekondu images from the 1950s to 1980s such as Zeytinburnu, Kağıthane and Altındağ are quickly completing their own integration process through spatial transformation, now discourse too shift to other areas. (Figure 21-24) Also, different from conventional gecekondu studies, which also focused on cities other than İstanbul, İstanbul now is the primary focus of the new discourse. There is a tangible tendency to observe new trends through İstanbul's experience and then to generalize them for Turkey as a whole. Highly populated urban areas at the outskirts of İstanbul such as Gaziosmanpaşa and Sultanbeyli become "trendy" focal points of fresh discourse of "varoş", "new immigration", "poverty" and "illegality". As the discourse shifts, so too does the image. This is a process of "in" and "out" as the popular expression has it. Sultanbeyli is "in" while Zeytinburnu is becoming "out". However, this is also due to obvious reasons. Discourse and surveys emphasize areas or neighbourhoods such as Gaziosmanpaşa, Pendik-Kaynarca, Küçükçekmece, Kadıköy-Fikirtepe, Kağıthane, Sultanbeyli and Ümraniye around İstanbul where low income groups are concentrated and the poverty reaches its peak (Özgen, 1999, 10).

"Urban poverty" then becomes the high theme increasingly referenced through the 1990s, and a direct connection is set between the gecekondu and urban poverty, which means that there is a direct connection between poverty and inhabitants of the gecekondu or similar areas. Researches show that poor living conditions in the gecekondu and/or in similar urban areas is not a temporary situation as it was generally considered. On the contrary, poverty is permanently associated with this type of urban areas. However, different than the terminology of "gecekondu people" which includes a priori meanings of a spatial reference, temporarity and integration with system, while "urban poverty" does not indicates any spatial link or concern, and has an obvious connotation of permanent exclusion from system. The mode of integration with the city of newcomers is also subject to change. To be established in the city is no longer a way to integrate with it as was the case in previous decades; instead it is now a life at the edge, slightly attached to the city but far from its facilities (Özgen, $1999,10)$. A research on this group highlights the following situations: "At the bottom, a very poor class unintegrated and disconnected and which is getting even poorer! They are not only limited to gecekondu inhabitants and represent even a larger group"; "it seems that, people demanding equal citizenship are not satisfied by the social state and they are trying 


\section{Varoștaki isyanın ekonomik fotoğrafı}

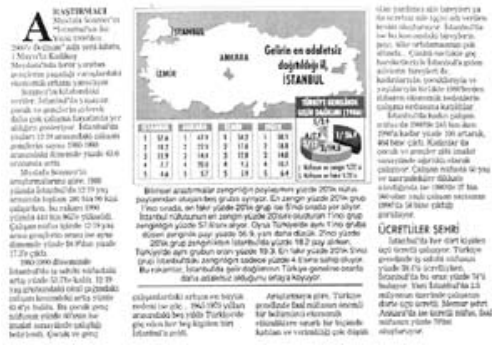

Figure 25. "Economic picture of uprising in varoshes".

Economic and social surveys and analysis on new panorama of gecekondus (now varoshes) take place in dailies to underline social inequalities and social fracture, as well as "anger of varoshes". (Hürriyet, 3 May 1996) to hold on to the city through a "resistance" mixed with illegality which is considered normal in the city" (Özgen, 1999, 18, 19). For example a survey on the urban poor of the Gaziosmanpaşa District, -a distant outskirt of İstanbul- reveals that they do not consider themselves as a part of İstanbul (Özgen, 1999, 13). Another survey of 1993 at the same spot emphasizes similar attitudes. Researchers get the impression that local people have a tendency to master the land where they settle, instead of to be adopted (Yavuz, 1997, 29). This dichotomy is not solely limited to the spatial structure of the city and indicates a social break that should not be considered normal. Thus, some events during 1990s provide sufficient reason to support similar points of views and contribute to the image of the "uncanny outskirts" in public opinion. Incidents at the Gazi District of İstanbul in 1995 and May Day in 1996 strengthen the associated image of "peoples from outskirts with tendency of violence" in perception of urban bourgeoisie. Particularly the day after the May Day 1996 where urban centre of Kadıköy District in İstanbul is seriously damaged, newspapers announce incidents as "Anger of varoshes" (Figure 25).

\section{TURN OF THE MILLENIUM AND THE TURN OF GECEKONDUS}

However, 1990's won't put an end to the gecekondu penomenon in Turkey. Perception will also change as the political climate changes where basic problem remains the same. At the beginning of the new Millenium, The main impetus policies towards gecekondus are shaped under one significant influence. Major earthquakes of the August 17, 1999 and the November 12, 1999 which hit the most populated and the most developed region of the Marmara in the north-west of Turkey and which cause huge loss of life (more than 20.000) and severe damage look no doubt the principal reason who influence nature of the problem and the way it is perceived and also solutions formulated. Islamists who took the government in general elections of 2002 and the majority of municipalities in local elections of 2004 adopt a general economic policy of liberalism mixed with pragmatisme in favor of big bourgeoisie and capital. The gecekondu policy of new era should be evaluated within economic pragmatisme of this new political elites and decision makers. In other words Turn of the Millenium marks a new era for gecekondus: new in implementations, in formulations but not in policy and discourse. The programme of the new governing party (The Justice and Development Party) emphasizes two major policies under the title of "urbanisation and housing":

- Instead of to rise densities in existing urban areas through new plans, urban improvement plans will be executed in gecekondu areas, and planning will be fastened in neighbouring metropolitan areas.

- Urbanization in an unhealty and ugly ways will be prevented and cities will be liveable areas. Affordable housing will be produced for gecekondu inhabitants.

The new discourse generated by the new political elites whether in government or in local administrations is based on the idea of clearence of gecekondus. This discourse looks very popular in theory, while not in favour of the poor in many cases. Gecekondus are now viewed since a long time a chronical problem which should be definitively dissolved. Therefore, new political elites begin to put a definitive end to most of existing gecekondu areas around major metropolitan areas if not to 
terminate the phenomenon. Under the influence of new rising liberal policies, it seems that there will be no room for gecekondus in cities, nor in the urban future of Turkey. This is completely a radical approach but not new to gecekondu phenomenon which puts them in a desperate situation. However, new radical policies to dissolve old gecekondu areas and to transfer their precious lands to new profitable real estate investments, also seems that they may have some promise for gecekondus at first sight, since an improvement not in gecekondu areas but in living conditions of dwellers are accentuated in some projects. Major characteristics of these projects were clearence of gecekondus and resettlement of dwellers into multi storey apartment blocks in outskirts of metropolitan areas. It is higly expected by decision makers that this kind of intervention will eventually improve living conditions of gecekondu dwellers and positively contribute general urban quality of the city since gecekondus will be cleared away. Therefore, one of major accent of new urban policies is the demolitions of gecekondus.

As previously mentioned, if there is something new in this approach, this is the aim, the size and speed of projects. New gecekondu policies of the millennium are primarily based upon one major policy tool: Urban regeneration. However, it seems that in many ways new policies are higly inspired by Gecekondu Prevention Zones and some similar policy tools of 1960's. This is particularly significant in gecekondu clearances and multi storey block housing estates built in cleared areas by Mass Housing Administration and/or by municipalities. However actors have changed. Role of the Ministry of Development and Housing is now replaced by Mass Housing Administration and municipalities. Again, new in implementations, in formulations but not in policy and discourse...

How this new policy and its arguments are perceived by the press? Attitude of the press towards this new policy is not completely in favour, nor is it against. In many cases press generally backed this new approach whether it also reflects some dramatic cases of urban clearence such as the events of Sulukule in İstanbul. Here a couple of examples will give an idea how this new policy is perceived and reflected through the press.

Early in 2000s "urban regeneration" policies and projects are introduced in Turkey particularly by a couple of metropolitan municipality as well as by government agencies such as Mass Housing Administration (Toplu Konut Idaresi). However in a couple of years real estate characteristics of urban renewal projects will become more visible while the initial aim to create earthquake secure urban areas is becoming less visible. In such circumstances a large scale urban regeration project by the Metropolitan Municipality of İstanbul is announced in 2004 by the press as follows:

\footnotetext{
"A giant urban regeneration project is debuted in İstanbul, the city with the highest amount of gecekondus in Turkey. Within the frame of the Regeneration Project, clearence of 1.500 gecekondus is started. The municipality will demolish 85.000 gecekondus and will resettle inhabitants into social housing units. According to a survey of 2003 by the İstanbul Metropolitan Municipality, a total of 85.423 gecekondus are determined in whole city. Therefore, the municipality prepared an Urban Regeneration Project and decided to clear all gecekondus."
}

Similarly, in a conference on Urban Regeneration and Real Estate Investments held in İstanbul by TOKİ and Urban Land Institue (ULI), President of the Mass Housing Administration (TOKI) declares that, gecekondu is among the major problems of Turkey. He continues; 
"More than 1.5 billion out of 6 in the world are living in squatters, in illegal buildings or are homeless and if this trend continues, the amount will reach 3 billions in the next 25 years. In developed countries people live moreover around cities whereas in developing or underdeveloped countries migrants who rush to cities to find a job, build large outskirts around urban areas which put obstacles to development of cities and causes significant economic losses... In big cities of Turkey, even around mid-size urban centres there exist gecekondus and illegal constructions. Therefore, for the first time in Turkey the last Government started a housing mobilization and a progress in urban regeneration through Mass Housing Administration at the centre. An amount of 285.000 units of housing is reached in more than 900 construction sites where 150.000 units are about termination... Urban regeneration is among the most difficult in the world and one of most important problems of Turkey since there will be no development for Turkey without solving gecekondu problem... Rural exodus to big cities should be prevented...T here are 3.200.000 housing units in İstanbul. Large amount of housing stock are built before the earthquake of 1999 and are standing still even they are not consistent with earthquake regulations and half of them should be renewed by the time. We should keep on going maybe by neglecting new defavourised areas in some parts of İstanbul. For regeneration of İstanbul, we should consider the city with an economic approach. Immigration can not be prohibited however some measures should be taken to prevent concentration of poor peoples in İstanbul and this can be done through security measures, through preventing illegals sheltering in İstanbul and thereby we may contribute to urban regeneration of İstanbul. Urban regeneration of gecekondus should anyway be done in İstanbul with legal support and government initiative without hurting people. Urban regeneration is now urgent in Turkey. We will accomplish this like the Spain and Korea." (Radikal, 2007a).

However, what is new in this era is not in discourse and familiar rhetorics in critic of gecekondu which also remain the same. These criticisms will no doubt contribute to the policy of clearence of gecekondus if not to support them. One of leading critics is speculative aspects of gecekondus. This is evidently the smooth side of the problem. A survey of İstanbul Chamber of Commerce on gecekondus of İstanbul will accentuate this speculative aspect and will gather interest and echoed in the press as follows (Figure 28):

"Gecekondus have also become a tool of speculation. Gecekondus which emerge only due to the need of shelter are became today a tool of speculation. According to information compiled from the survey on "Causes of Illegal Buildings in İstanbul" made by İstanbul Chamber of Commerce, one fourth of gecekondu dwellers who participated an interview, have declared that they do not own homes they live in. $42 \%$ of gecekondu inhabitants have declared that they bought the land of their homes from someone else and $18 \%$ bought the land with the home together and $68.4 \%$ posses ownership rights of homes they live in. And a majority of $50.9 \%$ told that they live on public lands without possessing any ownership certificate. According to the survey, plan of house is mostly done by owner. 58.8\% of houses are built by occupant, $21.7 \%$ by previous owner and $17 \%$ by a construction master, $1.1 \%$ by an engineer-architect and $0.9 \%$ by a developer on an agreement of land sharing. $87.2 \%$ of buildings have no permission of lodging. For only $10.3 \%$ of buildings a permission of use is claimed. On the other hand, $2.5 \%$ of interviewed subjects suggested that they did not know whether they have a permission of lodging or not. Self-builders for buildings without of a permission of lodging reached the biggest ratio of $52.1 \%$. Major reason to oblige people built illegaly is economical with a ratio of $76.9 \%$ among interview subjects. Whereas, $13.3 \%$ claim high cost of building licences, $7.7 \%$ bureaucratic difficulties, $1.5 \%$ lack of an urban development plan and $0.7 \%$ possibility of a urban amnesty law." (Radikal, 2007b) 
Chairman of İstanbul Chamber of Commerce claims that gecekondus were built for speculation from the very beginning. Some people who seized state owned lands divided them into plots and sold to immigrants for to build gecekondus:

"These people built their own shelters. By the time as immigration increased, gecekondu owners took the majority and they first established their own neighbourhoods, then grew up to become districts. Therefore 19 districts of İstanbul now reached to be 32. And gecekondus became a good for trade. Today $50 \%$ of gecekondus are for rent and prices are highly variable according to location, where for areas near city centres or with a view of the Bosphorus prices exceed some 50 billion TL" (İstanbul Ticaret Odas1, 2004).

According to press news, the major accent of this survey is to show that the leading motivation to build gecekondus from the very beginning is speculation. This is no doubt an exageration who put all the blames of urban problems on gecekondus but anyway a reference point enough important to show dissolution of gecekondus will be backed by the bussiness circles and capital.

However what happens until now, and the present cases show that critics did not gather much interest in public opinion and remained highly limited to professional circles and a handful of inhabitants of cleared areas. In other words, most significant criticisms and maybe the only important opposition come from professional circles particularly by Chamber of Urban Planners and Chamber of Architects and a couple of universities. Here a call for traditional celebration of spring jointly organized by inhabitants of Sulukule neighbourhood in İstanbul and supporting ngo's including professional organizations of architects and urban planners illustrates tones and content of these critics (31).

\section{PUBLIC ANNOUNCEMENT}

Sulukule, the victim of urban regeneration, celebrates its "day of rebirth" amongst ruins...

Day of Hidırellez is more meaningful this year for Sulukule. Sulukule is now like a ghost town one can only came across in urban war fields. In spite of demolitions ceased since sometimes, every day children are wounded among debris and ruins left haphazardly.

People of Sulukule whose lifes are ignored, celebrate the day of Hidirellez which represent refreshment of life and nature with hope and with joy of life in persistently to mentality who ignores them...

This time people of Sulukule burn the fire of Hidırellez at the magnificient heritage of history, the Sulukule Gate of city walls, just next to their demolished homes to salute all İstanbul which is faced by the same threat...

We expect your participation for to have fun, for solidarity and for to call out the voice of İstanbul.

31. The Platform of Sulukule (Sulukule Platformu); May 4, 2008.

\section{The Platform for Sulukule}

The Sulukule neighbourhood within the historic part of the city becomes a leading symbol of urban clearences of the new policy and popular resistance against them since it is one of first to subject urban clearences. It also represents the most touched in this manner with a significant civil initiative resisting to gentrification clearence in its wildest.

Chamber of Urban Planners which is one of forerunners in criticizing new urban clearecences has adopted an approach to consider new urban "regeneration" policies within the broader frame of globalisation 
of capitalism as illustrated below. This is an extract from an almost comprehensive critic of urban regeneration policy and implementations. It is also a good example to show how this new era of urban policies is perceived by professionals.

"Today, with the globalisation process, our cities are in a search of radical spatial, economic, politic and social transformation... Through the fetishism of restructuring and transformation concepts, our cities which are faced with destructive demands of capital and concentrated more on consumption than production is redefined through this new era based upon flexible production and flexible organizations. New times which show of all us that anything can not escape of being materialized, our cities also became a good of consumption through concepts of competition, local entrepreneurship and governance.

This new economic frame which is dominant on almost everything global still has a destructive influence upon our cities even in a crisis. The capital perceives whatever local as an economic input, also redefines our cities as the space of inequalities while it transforms structure of our cities with new shapes... All through this process, winners and losers are defined in cities, inequality increases and urban space is reshaped and spatial division of classes is becoming deeper. Cities of Turkey also become space of conflict between winners and losers, as it happens in other global cities. Through this restructuring, winners are working to raise urban land values while losers are forced to leave their lands. Through this new and destructive process, multi nationals and developers are becoming new owners of cities while the only way to be left for losers is to accept exile, out of the cities into the semi rural fringes of metropolitan cities. However, governments are in collaboration with an understanding which perceives cities as a good for trade and which foster inequalities within urban space... Questions about urban transformation scenarios and the very reality that urban losers will keep to rise, still remains unanswered. Yet, questions about the share of towns other than world citiess are also not precisely answered... In the case of Turkey, national development is closely attached to success of winning cities. However, the diversity between the urban and the regional keeps on growing and deepening" (32).

Major accent of this declaration is no doubt urban inequalities created by urban regeneration policies, largely based and influenced by global neoliberal policies. Relations between global capital and its reflections on local scale is important, as urban regeneration policies are the most interpreted and accentuated part of this declaration. It is not surprising that "defense of cities" is adopted as the most important problem and the general slogan by the Chamber of Urban Planners is to face threats generated by urban regeneration policies, since they are perceived as part of general, large scale destructive attacks of global neo-liberal policies.

\section{CONCLUSION}

The perception and meaning of the gecekondu in Turkey has considerably changed through time since the first emergence of gecekondus in late 1930s, but mostly after 1940s. In this paper, how the perception and meaning changed as the gecekondu transformed from a temporary oneroom hut to a permanent multi-storey concrete object of speculation and political dominance, has been discussed. However debate is mostly made through references to gecekondus of İstanbul. Because the case of İstanbul represents a more elaborate, colourful, diverse and ultimate version of gecekondu history in Turkey. Change and transformation of gecekondus 
in İstanbul, whether physical or in meaning, matches the chronological categories above, more than any other city does in Turkey. Gecekondus of İstanbul are generally and relatively more transformed through time, than any major gecekondu conglomerations of Turkey, such as those in Ankara or in İzmir, as mentioned in the introduction. One significant outcoms of this is that each city may have its own particular gecekondu history, which is especially perceptible in details. The gecekondu experience of various cities of Turkey may represent unique characteristics which are not always necessarily repetitive. Thus, chronological categories and transformations that gecekondus underwent through time can not be generalized always to the total gecekondu experience in Turkey. A general approach is adopted in this article due to practical reasons.

The 1950s and 1960s were somehow a period of innocence with regards to Turkey's gecekondus. Indeed, marginality and innocence is rather an appropriate definition of gecekondus in the post-war period to the 1970s. All throughout this period, inhabitants of gecekondus economically, socially and culturally represent a general marginal existence. This is because they are attempting to deal with harsh living conditions and are situated at the periphery of major cities. This is the best solution they can find to secure shelter under prevailing circumstances. First "surprise", then "anger" and later still "pity" are appropriate descriptions of the paradoxical perception of first generation gecekondus in urban public opinion.

The gecekondu clearly becomes an attractive subject for scientific research and studies from the 1960s onwards, particularly and a considerable volume of empirical research and surveys was realized between 1960 and 1980. Indeeed, research and surveys of this period contribute significantly to understanding of the phenomenon in practice as well as theory, leaving lasting traces on academic study into the topic.

For many aspects of the gecekondu, 1980 marks an important turning point. Not only the characteristics of the gecekondu phenomenon, but even the means of perception and discourse on gecekondu changed significantly. İstanbul was now the focus of all changes of the post-1980 period. This was mostly due to the type of urbanisation İstanbul experienced beyond 1980, through which, it underwent an 'original' means of development of urban space, other than under public or government leadership and the influence of the land market. İstanbul was now a metropolis, mostly but not exclusively comprising illegal development, not only due to its spatial structure, but also because of its social and cultural characteristics which gave birth, shape and legitimacy to an urbanisation process without an urban plan. It was also one of the world's few real 'multi-cultural' and 'pluralist' urban centres worth of being a 'dream city' or a 'heaven' for 'post-modernist thinkers', sheltering and accommodating urban spaces and spatial production processes and various cultures so different from one another, where east and west, north and south met in one large urban space. As illustrated by an expert;

“İstanbul is no longer an urban structure to be interpreted separately from immigration and immigrants. It has become a superposition. It is possible to encounter diverse space and life in the same location" (Özgen, 1999, 17).

Following rapid urbanization after 1950s, many surveys, research and studies are carried out in Turkey. Gecekondu studies in general concentrate on housing shortage, the elimination-improvement-prevention trio, land speculation, infrastructure, public services, criminality, social 
transformation, and political behaviour and urbanisation themes (Kartal, 1983, 40). The 1980s also mark a period in which empirical studies and field surveys were increasingly replaced by discourse. But this is almost a common position in Turkey for academic urban studies of this period in general, and is not necessarily limited to gecekondu studies. The rise of the 'varosh' terminology in the 1990s is also more than a simple definition but a total discourse encompassing all problem areas and aspects of the gecekondu phenomenon. Cultural fractures, illegality, identity crisis, poverty and violence emerge as some leading sub-topics and discourse areas under this general title.

However, gecekondu underwent various stages of perception parallel to many qualitative and quantitative transformations since it first appeared. As a result, feelings of 'compassion' and the 'strange attitude' of the bourgeoisie towards early gecekondus which superimpose the image of the fragile, shabby, one storey individual little house with a garden, sheltered in the outskirts and fringes of a city is replaced by an image of the "angry varosh fighting against of his/her city". And at each stage of this perceptional spectrum, the gecekondu is always viewed as the "other". However, the "varosh" represents a more significant expression of social dichotomy and fracture than the gecekondu. Therefore, the varosh becomes a more significant representation of the "other" than the gecekondu, bearing an image of threat towards the system that totally contrasts with the perceived innocence of the gecekondu. Presumptions of the temporary nature of the gecekondu also changed over time due to the changing nature of the phenomenon. One of the major novelties brought about by this conceptual transformation is the association of the gecekondu with poverty. Parallel to the rise of urban poverty in the 1990s as a new concept, this connection became more and more referenced. Even further, new dramatic definitions such as the 'urban poor' came into the agenda. One important outcome of this paradigm shift is that the phenomenon lost its spatial references, becoming considered almost solely within the context of social stratification independant of spatial location or relation.

Here, one major question arises about the ratio the perception reflects the reality. The general perception of the reality as public opinion, is indoubtly influenced and reflected through the mass media and the press. No doubt this was not a pure reflection of reality, but an interpretation of it. Therefore, we may talk of an interpreted reality, shaped by dominant cultural, political and ideological values of each era. Here, academic debates and interpretations should be excluded and considered within another framework, since they do not always and necessarily complain with approaches and views of mass media and press.

However, we may also think that today we are still far to understand the real conditions, and the pure reality of gecekondus, particularly in its eary years, since almost all the informations we have is about interpretations of the reality in some way or other. The fact that every categorization in the gecekondu history and the periodical denominations are highly influenced by media, or academic interpretations should be taken into consideration.

All through the history of the gecekondu, two major approaches to the phenomenon are visible in academic circles and among scholars and experts. An approach which is more critical and close to modernist ideals to defend modernist urban values, is the first, and the conception of gecekondu based upon the issue of social transformation, is the second. The 
first critical approach stresses more on qualitative aspects of gecekondus since it is supposed to represent an irrational way of urbanization:

"Following the rapid urbanization after 1950s, urban development of our big cities was managed by 'peasant planners'. The huge masses of 'peasant planners' who migrated to urban centres from the countryside, built large gecekondu areas in cities. They put and executed the rules by themselves. Neither 'scholar' planners nor 'politician planners' could cope with this. As a matter of fact they did not want to prevent it. Politicians and 'peasant planners' in collaboration with each other, gave way to the birth of an urbanization, as well as the emergence of an urban form which had a high social cost.

Findings of this research prove that gecekondu is more costly than social housing supplied by the public... This is due to the 'type of urbanization' in Turkey. This 'type of urbanization' assigns several functions to gecekondus, more than that of a 'house'. A way of wealth accumulation, a tool for investment of private savings, a tool of social security, a place of living in the city without giving up rural values, a milieu of agricultural and marginal production, etc" (Kartal, 1983, 27).

Through the years of 2000, clearence of gecekondu areas and relocation of dwellers in multi-storey block apartments under the campaign of "urban regeneration" became more visible and dominant as policy choice for Turkey, parallel to the adoption of neo-liberal policies. However, these should be considered as a re-membrance and re-application of old gecekondu prevention policies from 1950s to 1970s, with couple of slight financial, administrative and legal touch, than being a novelty. What is interesting in this policy choice is that, these types of policy implementations Turkey once experienced were highly criticized in the past: in spite of the un-experienced public administrators and politicians, expert planners also tackled the problem through classical formalist approach. This means that, gecekondus are forced into block apartments (and most of them would not fit), in order to find a 'solution' to a structural problem, since block apartments had and have a familiar image for the system. The solution should be interpreted as to clearing up 'the image of gecekondus' from the system or 'to dismiss gecekondus from the image of the system'. The relocation within the physical space would impose considerable costs for the society (Şenyapili, 1978, 63).

Consequently, major outcomes of the debate can be outlined as follows:

1. Perception of gecekondus as public opinion and particularly by the urban bourgeoisie changed parallel to many qualitative and quantitative transformations that gecekondus underwent in time. This perception varied from the 'feelings of compassion' to that of the 'angry varosh'.

2. There was a reciprocal relation between the public opinion and the mass media in terms of influence. The general perception of the reality in public opinion was influenced by the mass media and press, and also this general perception and attitude was reflected through media and press.

3. What was reflected through the media-press was generally not a pure reality but an interpretation of it. There was an interpreted reality, shaped by the dominant cultural, political and ideological values of each era. However, fields of academic debate and interpretation generally remained as exceptions, since they do not always correspond with views of the media-press. 
4. Attitudes of the public opinion and particularly the way views and news reflected and interpreted through the media-press considerably and primarily effected gecekondu policies of the governments.

5. The media and press generally perceived and reflected gecekondu phenomenon through a modernist approach, considering gecekondus as 'an irrational way of urbanization' that 'threatens modernist ideals and values'. Thus, they tackled with gecekondus on the basis of its image being 'a tool of degeneration of the system', and defended that it should be eliminated.

6. The media and press generally neglected the optimistic and academic view of gecekondus, which defended it to be the physical appearence of a comprehensive social transformation.

More than half a century long gecekondu adventure in Turkey has somehow resulted in a different manner than generally presumed. Integration with the city did not happen as had been assumed and expected initially. The modernist discourse dominant throughout gecekondu studies of the 1960s and 1970s in particular, was optimistic and self-confident, expecting gecekondus to become urbanized within "three generations at most" (33). At this new stage of their lives, immigrants consciously preferred to be "new inhabitants of the new place", developing new sub-cultures, group identities and interests. In addition to social and cultural delusions, spatial expectations were also unfulfilled. Within the context of the planned "modernist" city and the "unplanned city" dichotomy, gecekondus claimed to pursue a covert war against urban image, as the object of a construction activity which miniaturized the historic and planned city within a couple of decades (Kuban, 1996, 400). Presumptions that gecekondus would somehow evolve into planned/ organised urban areas were not realized. Indeed, plans for these areas only resulted in an excessive increase in building density, and worsened infrastructure, public services and open area standards (Akbulut, 1996, 358).

However, the gecekondu phenomenon is also considered in a favourable manner, as an original means of urbanisation and modernisation arising from the prevalent structural conditions of a 'peripheral' country. It represents a potential point of influence on political life, which gives it a more 'urbanised' nature due to the tendency towards rapid urbanisation. According to an assessment in the mid-1970s, as a result of rapid urbanization, the major type of politicians in the parliament would somehow be 'urban man' instead of a 'rural politician', empowered by his / her influence over the rural side (Okyay et al., 1975, 13). The optimistic assumption of this assessment is also highly debatable when actual conditions are considered.

Finally as a Turkish social scientist underlined:

33. "Because cities are places for the individual, it was expected that rural people immigrating to cities would somehow give up the values of their rural community, adopt a new way of life according to rational production-consumption relations of the city and become urbanized through the social and economic spaces the city provides. But the linear, progressive plan of modernism, expected by sociologists to be accomplished in "three generations" was never fulfilled" (Yavuz, 1996)
"Gecekondus belong to our people who migrated from villages and small towns, but problems they caused in many ways belong to short-sighted civil authorities... What Hart had underlined as the problem of the gecekondu people was "legality". The problem is the same through 1960s to date. We did not arrive to a position to legalize homes built by our people. What has been achieved through all the struggles, unachieved aims and unreasonable fears for 40 years ?" (Erdem, 2004). 


\section{BIBLIOGRAPHY}

ABRAMS, C. (1964) Man's Struggle for Shelter in an Urbanizing World, MIT Press, Cambridge, Massachussetts.

AKBULUT, M. R. (2003) Zeytinburnu'nda Mekansal Dönüşüm, Surların Öte Yanı Zeytinburnu, ed. by B. Evren, Zeytinburnu Belediyesi, İstanbul; 186-208.

AKBULUT, M. R. (1996) Kaçak Yapılaşmış Alanların Kentle Bütünleştirilebilmesi için Bireysel Projeler Yöntemi, Metropolün Geleceğine Yönelik Öneriler, Habitat'a Doğru İstanbul 2020 Sempozyumu, Bildiriler Kitabı (17-19 April 1996) L. Berköz Akkal, Ö. Ertekin, M.A. Yüzer, eds, İTÜ, İstanbul; 353-66.

AKKAYAN, T. (1979) Göç ve Değişme, İstanbul Üniversitesi Edebiyat Fakültesi. İstanbul.

ASLAN, Ş. (2004) 1 Mayıs Mahallesi, İletişim Yayınları, İstanbul.

ATAY, F. R. (1969) Çankaya, Doğan Kardeş Matbaacılık, İstanbul.

BADEMLİ, R. R. (1986) Türkiye'de Kentsel Araştırmaların

Gelişimi:1974-1984, Türkiye'de Sosyal Bilim Araştırmalarının Gelişimi, Türk Sosyal Bilimler Derneği, Ankara; 295-309.

CANTÜRK, F. (1962) Gecekondular, Sefalet Yuvaları, Milliyet (Newspaper), 1-2 November 1962, İstanbul.

ERDEM, T. (2004) Gecekondu, Radikal (Newspaper), 18 March 2004, İstanbul.

ERDER, S. (1996) İstanbul'a Bir Kent Kondu Ümraniye, İletişim Yayınları. İstanbul.

ERMAN, T. (1997) Squatter (gecekondu) Housing Versus Apartment Housing: Turkish Rural-to-Urban Migrant Residents' Perspectives, Habitat International, v: 21, n: 1, March 1997; 91-106.

ERSOY, M. (1985) Göç ve Kentsel Bütünleşme, Türkiye Gelişme Araştırmaları Vakfi, Ankara.

GENCAY, M. (1962) Gecekondu Problemi, İmar ve İskan Bakanlığı Komisyon Raporları No: 6, Ankara.

GÖKÇEN, T. (2003) Zeytinburnu Gecekonduları: Surları Öte Yanı Zeytinburnu, ed. by B. Evren, Zeytinburnu Belediyesi. İstanbul; 182-4.

GÖRGÜLÜ, A. Z. (1993) Hisseli Bölüntü ile Oluşan Alanlarda Yasallaştırmanın Kentsel Mekana Etkileri, YTÜ. İstanbul.

GÜREL, S. (1997) Gecekondu'dan Kaçak Kent'e, Kent Gündemi (1) January 1997, TMMOB/Şehir Plancıları Odası; 24-6.

HART,C.W.M., and SARAN, N. (1969) Zeytinburnu Gecekondu Bölgesi, İTO, İstanbul.

İLYASOĞLU, A. (1997) Ümraniye' den İnsan Manzaraları, İstanbul (23) October 1997; 92-100.

İMAR VE İSKAN BAKANLIĞI, Mesken Genel Müdürlüğü (1965) Ankara Esat, Çankaya ve Dikmen Gecekonduları, İmar ve İskan Bakanlığı, Ankara. 
İSTANBUL BÜYÜKŞEHİR BELEDİYESİ (2004) İstanbul Büyükşehir Belediyesi'nden Dev Kentsel Dönüşüm Projesi, 26 July 2004, www. yapitr.com.

İNANKUL, S. (1990) Planlama Politikaları Açısından Gecekondu Sorununa Genel Bakış: Kentsel Gelişmede Islah İmar Planlarının İşlevsel Özelliklerinin İncelenmesi: Bakırköy Örnekleri, unpublished Ph.D. Dissertation, Mimar Sinan Üniversitesi, Fen Bilimleri Enstitüsü, İstanbul.

İNŞAAT MÜHENDİSLERİ ODASI (1984) Gecekondu, Türkiye Mühendislik Haberleri, (308) March-April 1984, TMMOB İnşaat Mühendisleri Odasi; 2.

İSTANBUL TİCARET ODASI (1994) İstanbul Ticaret Odası'nın Önerisi, İstanbul, (11) October 1994, 78-79.

İPEKÇİ, İ. C. (1970) Büyük Şehrin Lanetlileri, Milliyet, 19 October 1970 İstanbul.

KARTAL, K. (1983) Ekonomik ve Sosyal Yönleriyle Türkiye'de Kentlileşme, Yurt Yayınevi. Ankara.

KELEŞ, R. (1986) 1951-1960 Yıllarında Kent Araştırmaları, Türkiye'de Sosyal Bilim Araştırmalarının Gelişimi, Türk Sosyal Bilimler Derneği. Ankara; 269-82.

KELEŞ, R. $(1983,1972) 100$ Soruda Türkiye'de Şehirleşme, Konut ve Gecekondu, Gerçek Yayınevi, İstanbul.

KILINÇASLAN. İ. (1981) İstanbul, Kentleşme Sürecinde Ekonomik ve Mekansal Yapı İlişkileri, İTÜ, İstanbul.

KIRAY, M. (1964) Ereğli: Ağır Sanayi Öncesi Bir Sahil Kasabası (Ereğli, A Coastal Town Before Heavy Industry), DPT, Ankara.

KONGAR, E. (1982) Kentleşen Gecekondular ya da Gecekondulaşan Kentler Sorunu, Kentsel Bütünleşme, eds. T. Erder, Türkiye Gelişme Araştırmaları Vakfı, Ankara; 23-54.

KUBAN, D. (1994) Yasadışının Tarihsel Zorunluluğu, İstanbul (11) October $1994 ; 80-82$.

MİLLIYET (1966) 40 Bin Gecekondu Suya ve Elektriğe Kavuştu, 1 July 1966, İstanbul.

MILLIYET (1966) Gecekondulara Tapu Dağıtmak Mizahtır,18 July 1966, İstanbul.

ÖZGEN, N. (1999) İllegalleşen Kent: İstanbul, Bilim ve Ütopya, November 1999, 9-19.

PULAT, G. (1992) Dar Gelirli Kentlilerin Konut Sorunu ve Soruna Sosyal İçerikli Mekansal Çözüm Arayışları, Kent-Koop, Ankara.

RADİKAL (Newspaper) (2007a) Bayraktar: Türkiye Gecekondu Problemini Çözmeden Kalkınmadan Söz Edilemez, 13 November 2007, İstanbul.

RADİKAL (Newspaper) (2007b) Gecekondular da rant aracı oldu, 22 February 2007, İstanbul.

SEYMAN, Y. (1986) Hüznün Coşkusu Altındağ, Gür Yayınları. İstanbul.

ŞENOL, S. (1996) İstanbul Kentinde 2. Dünya Savaşı'ndan Sonra Gelişen Yasal Olmayan Konut Tipleri ve Oluşum Nedenleri Üzerine Bir 
İnceleme (Zeytinburnu Örneği), unpublished Master Thesis, Mimar Sinan Üniversitesi, Fen Bilimleri Enstitüsü, İstanbul.

ŞENYAPILI, Ö. (1981) Kentleşemeyen Ülke Kentlileşen Köylüler, ODTÜ Mimarlık Fakültesi, Ankara.

ŞENYAPILI, T. (1998) Cumhuriyet'in 75. Yılı Gecekondu'nun 50. Yı11, 75 Yılda Değişen Kent ve Mimarlık, Türkiye Ekonomik ve Toplumsal Tarih Vakf1, İstanbul; 301-16.

ŞENYAPILI, T. (1986) 1960-1970 Yilları Arasında Kent Planlama Araştırmalarının Gelişimi, Türkiye'de Sosyal Bilim Araştırmalarının Gelişimi, Türk Sosyal Bilimler Derneği, Ankara; 283-94.

ŞENYAPILI, T. (1985) Ankara Kentinde Gecekondu Gelişimi (1923-1960); KentKoop, Ankara.

ŞENYAPILI, T. (1981) Gecekondu 'Çevre' İşçilerin Mekanı, ODTÜ Mimarlık Fakültesi Yayını, Ankara.

ŞENYAPILI, T. (1980) Squatter Settlements. A Bibliography, ODTÜ Mimarlık Fakültesi Yayını, Ankara.

ŞENYAPILI, T. (1978) Bütünleşmemiş Kentli Nüfus Sorunu, ODTÜ Mimarlık Fakültesi Yayını, Ankara.

TAHSIN, O., GÜLER, A. (1960) Taşlıtarlada Bir Buçuk Ay Yaşadım, Hayat; 20-1.

TEKELİ, İ. (1994) The Development of the İstanbul Metropolitan Area: Urban Administration and Planning, IULA-EMME, İstanbul.

Alınd1: 19.07.2005; Son Metin: 26.06.2010

Anahtar Sözcükler: gecekondu; kent tarihi; kentleşme; kentsel dönüşüm; Türkiye.

\section{GECEKONDU OLGUSUNUN ALGILANMASINDA YAŞANAN DÖNÜŞÜM}

Bu çalışmanın amacı, ne gecekondu olgusunun yeni bir tanımını yapmak, ne de tarihsel gelişimini yeniden betimlemektir. Bunun yerine, olgunun zaman içinde geçirdiği değişim ve dönüşümlerin kamuoyu tarafından algılanma biçimini araştırmak ve tartışmak, bu yazının temel hedefi olmuştur. Yine de, çalışma kapsamında akademik yaklaşımların genel olarak daha çok vurgulandığı söylenebilir. Çalışmada gecekondu olgusu, bu konuyla ilgili çalışmalardan da oldukça iyi bilinen tarihsel dönemlemelere uygun bir şekilde ele alınmıştır. Buna göre, 1940'lardan 1970'lere kadar olan 'masumiyet ve marjinallik' dönemi; 1970'li yılların 'politikleşme ve toprak spekülasyonundan ilk kez kazanma' dönemi ile, 1980 sonrasından günümüze uzanan yaygın spekülasyon ve yasadışılığın egemen olduğu 'varoş' dönemidir. Çalışmada gecekondu olgusu, yukarıdaki dönemlere uygun olarak değişip, dönüştükçe kamuyounda olguya ilişkin algılamanın da değiştiği varsayılmış ve çalışma bu kabule göre biçimlenmiştir. 
MEHMET RIFAT AKBULUT; B.C.P., M.C.P., Ph.D.

Graduated from Urban and Regional Planning Department of METU (1986). Received Master in Urban Conservation in 1992 at Mimar Sinan University, İstanbul and Ph.D. in 2004 from the same university. Teaches and continues his research on urban history, urban transformation and spatial analysis, at the Urban and Regional Planning Department of the same university. rifat@msgsu.edu.tr

SEHER BAŞLIK; B.C.P., M.C.P., Ph.D.

Graduated from Urban and Regional Planning Department of the Mimar Sinan University (1993). Received Master's degree in Urban Planning in 2003 and Ph.D. in 2008 from the Urban and Regional Planning Department of Mimar Sinan Universityİ stanbul. Teaches and continues her research on urban transformation, advanced spatial models and analysis at the Department of Informatics of the same university. seherb@msgsu.edu.tr 